\title{
内部摩擦をもつ粘性土の地震時受働土圧の算定 \\ CALCULATION OF PASSIVE EARTH PRESSURE DURING EARTHQUAKE FOR COHESIVE SOILS POSSESSING INTERNAL FRICTION
}

\author{
市 原松 平* 中 根 進** \\ By Matsuhei ICIHARA and Susumu NAKANE
}

\section{1. まえがき}

粘性土からなる基礎地盤の強さが粘着力上内部摩擦角 であらわされるときの地震時受働土圧注常時の場合と同 じように，簡便法息で近似的に求为られる。しかしなが ら地震力が大きくなると簡便法で求められない場合もあ る. この研究は擁壁の前面の傾角, 基礎地盤の天端面の 傾角を変えて，また地盤士に種々の大きさの地震力を作 用させて，受働土圧を算定したものである．耐震設計に 使用する地盤の土の強さとしては $c_{u}, \phi_{u}$ を使用するが， ここでは便宜上これらをそれぞれ $c$ ， 上略記する.

一般に塑性論に基づいて,壁面の土圧を求好ときに, 受働土压では壁の前面の地表面（主働土圧では壁の背面 の裹込为天端面）の境界条件と地盤に接した壁面の境界 条件を結ぶ方法として, 特異点の条件を使用する.ここ ではこれを特異点の解と略記する。しかしながら壁面と 地表面之のなす角度が小さな場合, 壁面上地表面にでき た両すべり線網が交差するために，特異点の解を用いる ことができない，この場合は，不連続線による解を使用 する.ここに示す受働土圧の一連の計算では上記の特異 点の解上不連続線の解を用いた.

特異点を用いて，壁面土圧を算定する場合に，Sokolovski は地表面から壁面に向かって算定を進める方法を 示した。しかしながら差分の計算法では, 電子計算機の 容量からいって，分割数をそれほど多くとることはでき ない。このため沉計算には誤差を生ずる，筆者らは Sokolovski ${ }^{11.2)}$ に従って計算を行ったが，より正確な值は どのようにしてえられるかを考究した.しかしながらこ の Sokolorski の方法はすべり線網を描く点においては 非常に便利であり, 後述する厳密解によるものよりも安 全側の結果が得られたので後述する表にはこの值を示し

* 正会員 工博 名古屋大学教授 工学部付属土王研究施設 ** 正会員 中日本建設コンサルタント（株）
た. 次に, 後者の不連続線による解は, 金属塑性論で Prager $(1953)^{3)}$ によって導入されたものである. 土質力学 への導入はまず Shield $(1953)^{4)}$ によって行われたが, 彼は土が重量を有しない場合について解いた. 不連続線 を使用して本格的に土の問題を解いたのは Sokolovski $(1957)^{5)}$ であ万う。彼はこれを用いて, 限界応力状態に おける 2 つの問題を解いたが，これらの問題はいずれも 地表面と原点における斜面の接線とがなす角度（または 原点における㩁壁の面とがな寸角度）がきわめて小さな 特殊な場合であって，筆者らの扱う擁壁に適用できな い. 筆者らはこれを解くのに Sokolovski にならって第 4 境界值問題 ${ }^{2}$ を適用したが，原点近傍の解を求める方 法としては, 高木 ${ }^{6)}$ が以前斜面安定問題でとった後述す る“べき級数に展開する方法”を用いた。

なお筆者らはこの計算結果を最近の Lee らの研究》之 比較した. Lee らは速度場を加味して, 壁摩擦角が $\delta=$ $\phi と \tan \delta=\sin \phi$ で与えられる 2 つの場合に静的の受働

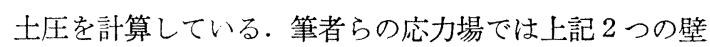
摩擦角では一般に不連続線を生じない。したがって $\phi$ の特巽点の解を Lee らと比較したが, Lee らの值は 筆者らの厳密解と一致した.さらに筆者らは, 以前行。 た粘性土の受働土圧を求める簡便法 ${ }^{8}$ による結果と比較 したが，これは厳密解と等しいかまたは幾分小さめの值 を与えていることがわかった。

筆者の一人は以前, 土中の鉛直面に作用する地震時主 働ならびに受働土圧をモールの円を用いて求めた ${ }^{11)}$. こ の方法は現在, 鉄筋コンクリート摧壁背後の土中の鉛直 面に作用する砂質土, 粘性土 $(c, \phi)$ の地震時主働, 受 働土圧の算定に使用されている ${ }^{9)}$. 次に土中の鉛直面で はなくて, 壁面に直接に作用する地震時土圧のうち, 受 働土圧は曲線のすべり面に基づく結果がまず必要であ。 たので, 砂質土に適用される砂の地震時受働土圧保数を その後求めた ${ }^{10)}$.またこの土圧係数を用いて, 内部摩擦 
をもつ粘性土の受働土圧の算定に挔張した ${ }^{8)}$.この研究 こよって,このような粘性土の受働土圧の大きさをすみ やかに見積ることはできるが，この簡便な方法では，す ベり面が求められず, また水平震度 $\tan \theta_{0}$ が内部摩擦 倸数 $\tan \varphi$ よりも大きな場合に，土圧を算定することが できない，したがって，ここに示した今回の報文は，こ のような実用上の問題にも答えることができる.

\section{2. 受働土圧算定法の説明}

図一1（a）に示すように，壁頂に原点 0 をとり，u-v 座標の $v$ 軸を地表面に, $n-t$ 座標の $t$ 軸を壁面に一致 させる. 壁面に作用する受働土圧を求める場合に, 地震 力は図に示すように，壁体から基礎地盤上に向かって水 平に作用すると考える.

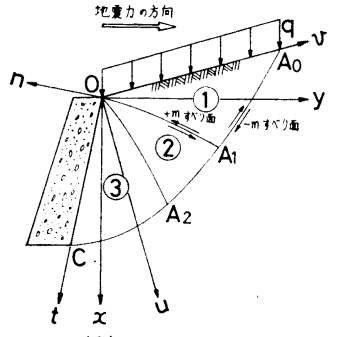

(a)

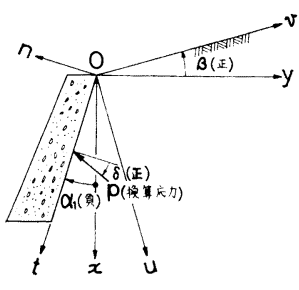

(b) 図一1（a), (b) 3つの領域と座標ならびに $\alpha, \beta, \delta$ の符号

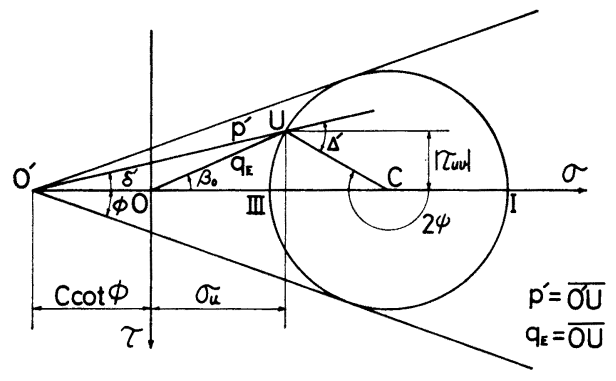

(c) 地表面

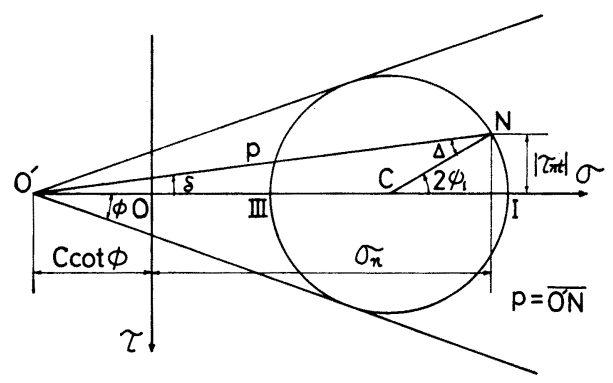

(d) 壁面

図一1（c),（d）地表面および壁面の応力状態 壁に接した基礎地盤は，一般に図一1（a）に示すよう に3つの領域にわけられる。 (1) は受働領域, (2) は遷移 領域, (3) は主働領域である.

Sokolovski は, 計算を地表面 ( $v$ 軸) から始好, 領 域 (1) は Cauchy 問題, 領域 (2) は Goursat 問題, 領 域 (3) は混合境界值問題をそれぞれ解くことによって, 壁面に作用する土圧を求めた. 以下 Sokolovski の方法 を㧪張して, 地震時受働土圧を求めるための境界值と漸 化式を示す.

\section{（1）地表面の条件}

地表面では，

$$
\left.\begin{array}{l}
\sigma_{u}=q_{E} \cos \beta_{0} \\
\tau_{u v}=-q_{E} \sin \beta_{0}
\end{array}\right\}
$$

ここに $\beta_{0}=\beta-\theta_{0}$ で $\beta$ は地表面の傾角（図一1 (b)), $q_{E}=q / \cos \theta_{0}, q$ は等分布載荷重, $\theta_{0}=\tan ^{-1} \alpha / g$ で， $\propto$ 㳉 水平加速度, $g$ 核重力の加速度である.

また図一1 (c) に示される地表面での換算荷重 ${ }^{2}$ を $p^{\prime}$, 換算荷重の地表面に対する傾角を $\delta^{\prime}$ とすると,

$$
\left.\begin{array}{rl} 
& p^{\prime} \cos \delta^{\prime}=\sigma_{u}+c \cot \phi=q_{E} \cos \beta_{0}+c \cot \dot{ } \\
& -p^{\prime} \sin \hat{o}^{\prime}=\tau_{u v}=-q_{E} \sin \beta_{0}
\end{array}\right\}
$$

上式から $\sigma^{\prime}, \phi, \widetilde{\sigma}$ を求めると, 受働状態では,

$$
\left.\begin{array}{l}
\tan \tilde{o}^{\prime}=\frac{q_{E} \sin \hat{\beta}_{0}}{q_{E} \cos \beta_{0}+c \cot \phi} \\
2 \phi=\hat{o}^{\prime}-J^{\prime}-\pi \\
\tilde{\sigma}=\frac{p^{\prime} \sin J^{\prime}}{\sin \left(J^{\prime}-\hat{o}^{\prime}\right)} \\
=\frac{\left(q_{E} \cos \beta_{0}+c \cot \phi\right)\left(\cos \delta^{\prime}+\sqrt{\cos ^{2} \tilde{\delta}^{\prime}-\cos ^{2}{ }^{\prime}}\right)}{\cos \tilde{\delta}^{\prime} \cos ^{2} \phi}
\end{array}\right\}
$$

ここに $\sin \Delta^{\prime}=\sin o^{\prime} / \sin \phi, \pi / 2 \geqq\left|\Delta^{\prime}\right|$, また $\varphi$ は最大主 応力面から計って $u$ 面までの角度で, $\widetilde{\sigma}$ はクーロンの 破壊包絡線の交点から計ったモールの円の中心までの距 離である。

\section{（2）壁面の境界条件}

図一1 (b) のように壁面に作用する換算応力を $p$ ， そ の壁摩擦角を $。$ 上する. 実応力は $\sigma_{n}$ と $\tau_{n t}$ である. 最大主応力面から計った $n$ 面までの角度を $\psi_{1}$ 上おく と次式が壁面で成立する.

$$
\left.\begin{array}{l}
p \cos \hat{\delta}=\sigma_{n}+c \cot \phi=\tilde{\sigma}\left(1+\sin \phi \cos 2 \dot{\varphi}_{1}\right) \\
p \sin \delta=-\tau_{n t}=\tilde{\sigma} \sin \phi \sin 2 \psi_{1}
\end{array}\right\}
$$

これから $\varphi_{1}=(\Delta+\delta) / 2, \sin \Delta=\sin \delta / \sin \phi, \pi / 2 \geqq|\Delta|$, $\phi_{1}$ を $u$ 面に関連付けて $\phi$ とかくと, $n$ 面之u面との 関係から， $\phi$ 注次式で与えられる， $\alpha_{1}$ は壁の背面の傾 角である。 
内部摩擦をもつ粘性土の地震時受働土玨の算定

$$
2 \dot{\psi}=\Delta+\delta+2\left(\beta-\alpha_{1}\right)-\pi .
$$

また壁面での換算応力 $p$ は次式で与えられる（図一1 (d)).

$$
p \cos \hat{\sigma}=\tilde{\sigma} \cos \delta\left(\cos \delta+\sqrt{\sin ^{2}} \hat{\phi}-\sin ^{2} \delta\right)
$$

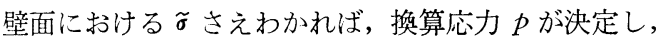
$\sigma_{n}$ 上 $\tau_{n t}$ は式 (5) より求められる. 各記号は図一1 (c), (d) に示される.

\section{（3）漸 化 式}

$\gamma \neq 0$ の場合には Sokolovski の導入した関数 $\xi, \eta$ を 座標にとり， $+m$ すべり面 ${ }^{11), 13)}$ ( $\eta$ 特性線) は $\xi$ の によって変化し， - $m$ すべり面 ${ }^{11), 13)}$ ( $\xi$ 特性線）は $\eta$ のみによって変化することはできない，この場合，Sokolovski はもっと一般的な座標 $\lambda, \nu$ を用い, $+m$ すべ

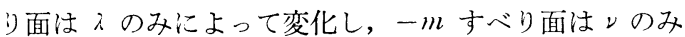
によって変化するとした．図一2 は図一1 (a)を 標面に写像したものである. 図一1 (a) の $O A_{0}$ は図一2 の線分 $\overline{O_{1} A_{0}}$ となる.

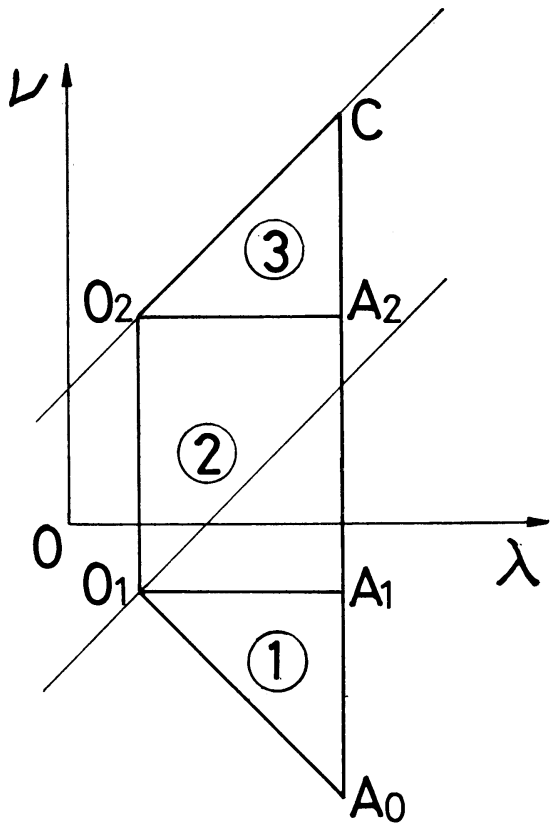

図-2 領域の写像

$\overline{O_{1} A_{0}}$ より計算をはじめる. 図一2の $\overline{O_{2} A_{2}}$ 上におけ る $u, \tau, \phi, \widetilde{\sigma}$ を決定するための漸化式, すなわち Cauchy 問題, Goursat 問題を解くための漸化式は以下のように なる。

$$
\begin{array}{r}
\left.u_{i, j}=\frac{v_{i, j-1}-v_{i-1, j}+u_{i, j-1} \tan \left(\phi_{i, j-1}-\mu\right)}{\tan \left(\phi_{i, j-1}-\mu\right)-\tan \left(\phi_{i-1, j}+\mu\right)}\right)^{*} \\
*-u_{i-1, j} \tan \left(\phi_{i-1, j}+\mu\right) \\
v_{i, j}=v_{i-1, j}-\left(u_{i, j}-u_{i-1, j}\right) \tan \left(\phi_{i-1, j}+\mu\right)
\end{array}
$$

$$
\begin{aligned}
& \tilde{\sigma}_{i, j}=\frac{\gamma\left(A C \tilde{\sigma}_{i, j-1}+B D \widetilde{\sigma}_{i-1, j}\right)+2 \tilde{\boldsymbol{\sigma}}_{i, j-1} \tilde{\sigma}_{i-1, j}}{\tilde{\boldsymbol{\sigma}}_{i, j-1}+\widetilde{\boldsymbol{\sigma}}_{i-1, j}} * \\
& \text { * } \times\left[1-\left(\psi_{i, j-1}-\psi_{i-1, j}\right) \tan \phi\right] \\
& \left.\begin{array}{r}
\psi_{i, j}=\frac{\tilde{\sigma}_{i-1, j}-\widetilde{\boldsymbol{\sigma}}_{i, j-1}+2 \tan \phi\left[\widetilde{\sigma}_{i-1, j} \psi_{i-1, j}\right.}{} * \\
2\left(\widetilde{\boldsymbol{\sigma}}_{i, j-1}+\widetilde{\boldsymbol{\sigma}}_{i-1, j}\right) \tan \phi \\
\left.+\widetilde{\boldsymbol{\sigma}}_{i, j-1} \psi_{i, j-1}\right]+\gamma(A C-B D)
\end{array}\right)
\end{aligned}
$$

ここに, $\mu=\pi / 4-\dot{\phi} / 2$

$$
\left.\begin{array}{l}
A=\cos \left(\beta_{0}-\phi\right) /\left(\cos \dot{\phi} \cos \theta_{0}\right) \\
B=\cos \left(\beta_{0}+\dot{\rho}\right) /\left(\cos \dot{\phi} \cos \theta_{0}\right) \\
C=u_{i, j}-u_{i-1, j}-\left(v_{i, j}-v_{i-1, j}\right) \tan \left(\beta_{0}-\dot{\phi}\right) \\
D=u_{i, j}-u_{i, j-1}-\left(v_{i, j}-v_{i, j-1}\right) \tan \left(\beta_{0}+\dot{\phi}\right)
\end{array}\right\}
$$

上式は既知の 2 つの節点 $(i-1, j),(i, j-1)$ から末 知の節点 $(i, j)$ の $u, v, \widetilde{\sigma}, \phi$ の值を決定する差分式で ある. また領域 $\triangle \mathrm{CO}_{2} \mathrm{~A}_{2}$ で表わされる混合境界值問題 を解くために，次の漸化式が用いられる.

$$
\begin{aligned}
& u_{i, j}=\frac{v_{i, j-1}+u_{i, j-1} \tan \left(\phi_{i, j-1}-\mu\right)}{\tan \left(\phi_{i, j-1}-\mu\right)-\tan \left(\beta-\alpha_{1}\right)} \\
& v_{i, j}=\frac{v_{i, j-1}+u_{i, j-1} \tan \left(\phi_{i, j-1}-\mu\right)}{-\tan \left(\phi_{i, j-1}-\mu\right)+\tan \left(\beta-\alpha_{1}\right)} \tan \left(\beta-\alpha_{1}\right) \\
& \tilde{\sigma}_{i, j}=\tilde{\sigma}_{i, j-1}+2 \widetilde{\sigma}_{i, j-1}\left(\phi_{i, j}-\phi_{i, j-1}\right) \tan \phi+\gamma B D
\end{aligned}
$$

上述の漸化式に用いられる $\phi$ の值は最大主応力面か ら計った $u$ 面までの角度で, 反時計まわりを正にとっ ている. Sokolovski では $u$ 面から最大主応力面に向か って計り，同じく反時計まわりを正にとっているので， Sokolovski の漸化式と $\phi$ の符号が異なることに注意を 要する.

上述の漸化式に打ける $r$ ，境界条件における $c$ と $r$ は，それぞれ $c=1 \mathrm{t} / \mathrm{m}^{2}, r=1 \mathrm{t} / \mathrm{m}^{3}$ とおいて漸化式と境 界值を無次元化しておく ${ }^{1)}$. したがって無次元化された 漸化式では $c=1, \gamma=1$ である. このような無次元化 は， 1 つの計算結果を利用して， $q=0$ の場合に種々の $c, r$ に対応する值をうるためである。

\section{（4）特異点の解の成立条件}

上述の解は原点を特異点と考えて, 解が求められる. これは壁面と地表面とのなす角度，すなおち 図一1 (a) の $\angle A_{0} O C$ が比較的に大きい場合にこの解法が可能で ある.もしもこの角度が小になると, 領域 (1) と (3)が重 なり合ってしまう。このような場合に，上述した特異点 の解は使用できない. 特異点の解が用いられる条件を次 式に示す.

$$
\left.2 \alpha_{1} \leqq \delta+\right\lrcorner-\delta^{\prime}+J^{\prime}+2 \beta
$$

\section{3. 不連続線による解}

\section{（1）不連続線上で成立する条件}


次式が成立する場合には，原点を通る不連続線によっ て土圧を求める.

$$
2 \alpha_{*} \geqq 2 \alpha_{1}>\delta+\Delta-\delta^{\prime}+\Delta^{\prime}+2 \beta
$$

ここに

$$
2 \alpha_{*}=\pi+2 \beta-\left(\bar{o}^{\prime}-\Delta^{\prime}\right)-2 " \mu
$$

これは図一3 で壁頂から発生する領域 (1) の最下端のす べり線が擁壁内に入らない条件から決定される.

いま不連続線に接した領域 (1)の $\phi$ と $\widetilde{\sigma} を \phi^{\prime}, \tilde{\sigma}^{\prime}$ と おき, 領域 (3)のそれらを $\phi, \tilde{\sigma}$ とおくと, 次式が成立 することが容易に証明される。

$\dot{\varphi}^{\prime}>\dot{\varphi}$

Shield ${ }^{4)}$ や Sokolovski ${ }^{11}$ は不連続線上で成立する条 件として次式を求めた。

$$
\left.\begin{array}{l}
\cos \left(\dot{\varphi}+\dot{\varphi}^{\prime}+2 \omega\right)=\sin \phi \cos \left(\dot{\varphi}^{\prime}-\dot{\varphi}^{\prime}\right) \\
\tilde{\sigma} \sin 2(\dot{\phi}+\omega)=\tilde{\sigma}^{\prime} \sin 2\left(\dot{\phi}^{\prime}+\omega\right)
\end{array}\right\}
$$

ここに示す $\phi, \tilde{\sigma}$ は不連続線上の值であるが，以下の 考察ではこの記号は壁面と不連続線との間における任意 の点で使用する．また $\omega$ は，不連続線上の接線が $u$ 軸 となす角度である. 式 (13)，(14）は主働, 受働に対し て成立するが，主㗢土圧では $\widetilde{\sigma} \geqq \widetilde{\sigma}^{\prime} ，$ 受㗢士圧では $\widetilde{\sigma} \leqq$ $\widetilde{\sigma}^{\prime}$ となる.この関係を满足させる 式で与えられる。

$$
2 \omega=-\left(\dot{\phi}+\dot{\varphi}^{\prime}\right)+k\left(\Delta_{1}-\frac{\pi}{2}\right)
$$

$$
こ こ に
$$$$
\sin J_{1}=\sin \dot{\phi} \cos \left(\psi-\phi^{\prime}\right)
$$

$k$ の值は主㗢土圧で $k=-1$, 受働土压で $k=+1$ であ 子.

受働土圧の場合に不連続線の勾配は,

$$
\frac{d v}{d u}=\tan \left(\omega=\frac{-\sin \left(\phi+\psi^{\prime}\right)-\sqrt{1-\sin ^{2} \phi \cos ^{2}\left(\phi-\psi^{\prime}\right)}}{\cos \left(\phi+\phi^{\prime}\right)+\sin \phi \cos \left(\phi-\phi^{\prime}\right)}\right.
$$

基礎地盤面が水平で，地震力がなく，等分布載荷重が 地表面に鉛直に作用するときには, $\phi^{\prime}=-\pi / 2$, したがっ て上式から次式が得られる。

$$
\frac{d v}{d u}=\tan \omega=\frac{\cos \phi-\sqrt{1-\sin ^{2} \phi \sin ^{2} \phi}}{(1-\sin \phi) \sin \phi}
$$

この式は Sokolovski が求めた式である.

\section{（2）不連続線による解法の概略}

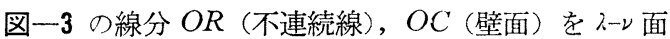
に図一4のように写像し, 特性線網を作る. OR, $O C$ に 沿らて, それぞれ $u, v$ と $\widetilde{\sigma}, \phi$ の間に微分比ができる と, $-m,-m$ すべり面に沿う微分比を連立させて, $O R, O C$ 線上の各節点の 4 值 $(u, v, \tilde{\sigma}, \phi)$ を求めるこ とができる.これらの 4 值を差分法で求めるときに，原 点の 4 值と原点近傍の 4 值が明確であれば, その 2 点か ら出発して，第 4 境界值問題 ${ }^{2}$ を解くことによって解が えられる。

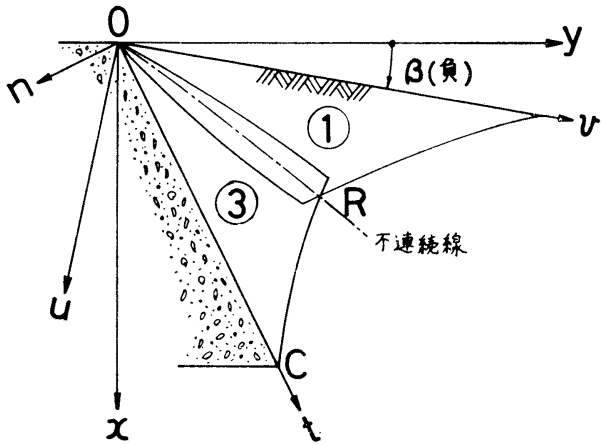

図一3＼cjkstart不連続線による解法の説明

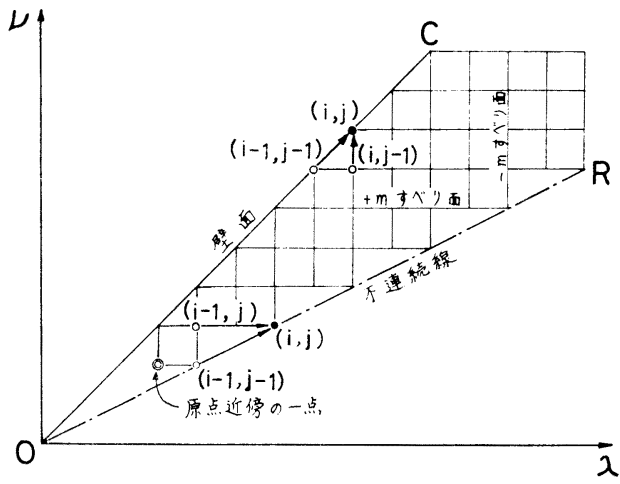

図一4第4 境界值問題の解法

\section{（3）不連続線上における $\boldsymbol{d} \tilde{\boldsymbol{\sigma}} / \boldsymbol{d} \boldsymbol{\phi}$ の決定}

式 (14) の第 1 式と第 2 式の両辺をそれぞれ $\phi$ で微 分し, 両式から $d \omega / d \psi$ を消去し, さらにその式を全微 分の形で表わすと,

$$
d \tilde{\sigma}=M d \dot{\phi}+\frac{\sin 2\left(\phi^{\prime}+\omega\right)}{\sin 2(\phi+\omega)} d \tilde{\sigma}^{\prime}-M d \dot{\varphi}^{\prime}
$$

こに，

$$
\begin{aligned}
& M=\frac{\widetilde{\sigma}^{\prime} \cos 2\left(\psi^{\prime}+\omega\right)(L-1)-\widetilde{\sigma} \cos 2(\phi+\omega)(L+1)}{\sin 2(\phi+\omega)} \\
& L=\frac{\sin \phi \sin \left(\phi-\psi^{\prime}\right)}{\sin \left(\phi+\phi^{\prime}+2 \omega\right)} \ldots \ldots \ldots \ldots \ldots \ldots \ldots \ldots \ldots \ldots \ldots \ldots \ldots \ldots \ldots \ldots \ldots \ldots \ldots \ldots \ldots \ldots \ldots \ldots
\end{aligned}
$$

また $\tilde{\sigma}^{\prime}$ と $\phi^{\prime}$ は次式で表わされる。

$$
\begin{aligned}
& 2 \phi^{\prime}=\tilde{o}^{\prime}-\Delta^{\prime}-\pi \\
& \tan \tilde{o}^{\prime}=\frac{\left(q_{E}+\gamma_{0} u\right) \sin \beta_{0}}{\left(q_{E}+\gamma_{0} u\right) \cos \beta_{0}+c \cot \phi} \\
& \tilde{\sigma}^{\prime}=\frac{\left[\left(q_{E}+\gamma_{0} u\right) \cos \beta_{0}+c \cot \phi\right]}{\cos \delta^{\prime} \cos ^{2} \phi^{2}} * \\
& * \frac{\left[\cos \delta^{\prime}+\sqrt{\cos ^{2} \delta^{\prime}-\cos ^{2} \phi}\right]}{}
\end{aligned}
$$

\section{（4）原点における $\phi, \tilde{\sigma}, \phi^{\prime}, \tilde{\sigma}^{\prime}, \omega$}

原点におけるこれらの值をそれぞれ $\widetilde{\sigma}_{0}, \psi_{0}, \widetilde{\sigma}_{0}{ }^{\prime}, \phi_{0}{ }^{\prime}$, $\omega_{0}$ で表わす． 不連続線上の原点の值は壁面の条件を満 足させなければならないので， $\phi_{0}$ は式 (6) に与えられ る.また $\phi_{0}{ }^{\prime} ， \widetilde{\sigma}_{0}{ }^{\prime}$ は受働時における $v$ 軸上の值で決定 
されるから, 式 (4) で与えられる.また $\omega_{0}$ は式 (15)，

(16) から次式で与えられる.

$$
\left.\begin{array}{l}
2 \omega_{0}=-\left(\psi_{0}+\phi_{0}{ }^{\prime}\right)+\Delta_{1}-\pi / 2 \\
\sin \Delta_{1}=\sin \phi \cos \left(\psi_{0}-\phi_{0}{ }^{\prime}\right)
\end{array}\right\}
$$

最後に残った $\widetilde{\sigma}_{0}$ は, 式 (14) の第 2 式から次式で与 えられる。

$$
\tilde{\sigma}_{0}=\tilde{\sigma}_{0} \frac{\sin \left(2 \psi_{0}^{\prime}+2 \omega_{0}\right)}{\sin \left(2 \psi_{0}+2 \omega_{0}\right)}
$$

\section{（5） $\boldsymbol{\phi}, \tilde{\boldsymbol{\sigma}}, \boldsymbol{v}, \boldsymbol{\omega}$ の原点近傍における近似解}

不連続線と壁面で囲まれた領域内の $\phi, \tilde{\sigma}$ ならびに不 連続線上の一点 $v$ と不連続線の接線の傾角 $\omega$ は原点近 傍で，べき級数に展開が可能6)であるので次のようにお $<$.

ただし実際の計算では，u，rのの一次または二次の項で 打ち切る.

$$
\left.\begin{array}{l}
\dot{\varphi}=\dot{\varphi}_{0}^{\prime}+a_{1} u+a_{2} v+\cdots \cdots \\
\tilde{\sigma}=\widetilde{\sigma}_{0}+b_{1} u+b_{2} v+\cdots \cdots \\
v=c_{1} u+c_{2} u+\cdots \cdots \\
(1)=\omega_{0}+\omega_{1} u+\cdots \cdots
\end{array}\right\}
$$

また第 1 の領域 $\psi^{\prime}$ と $\tilde{\sigma}^{\prime}$ に関して原点近傍で次のよ らにおく.

$$
\left.\begin{array}{l}
\dot{\varphi}^{\prime}=\dot{\varphi}_{0}^{\prime}+f u \\
\widetilde{\sigma}^{\prime}=\widetilde{\sigma}_{0}^{\prime}+g u
\end{array}\right\}
$$

上記の $a$ ，から $g$ に至る 9 個の未定係数を決定するに あたり， $d v / d u=\tan \omega$ に式（24）の第 3 式を代入して，

$$
c_{1}=\tan \omega_{0}
$$

また第 $3 ， 4$ 式から

$$
c_{2}=1 / 2 \cdot \omega_{1} \cdot \sec ^{2} \omega_{0}
$$

壁の背面は $v=u \tan \left(\alpha_{1}-\beta\right)$ で与えられるから，壁の 背面の $\phi$ は $\phi=\phi_{0}+u\left\{a_{1}+a_{2} \tan \left(\alpha_{1}-\beta\right)\right\}$, しかるにこ の值は ルに無関係であるから，

$$
a_{1} / a_{2}=-\tan \left(\alpha_{1}-\beta\right)
$$

したがって，式（24）の第1式は次のようにかける.

$$
\dot{\psi}=\varphi_{0}+a_{2}\left\{v-u \tan \left(\alpha_{1}-\beta\right)\right\}
$$

不連続線上で, $v=c_{1} u$ とおくと,

$$
\dot{\varphi}=\dot{\varphi}_{0}+a_{2} u\left\{c_{1}-\tan \left(\alpha_{1}-\beta\right)\right\}
$$

領域 (1)の応力 $\sigma_{u}$ ならびに $\tau_{u v}$ は，それぞれ次式で 表現される。

$$
\begin{gathered}
\begin{aligned}
\sigma_{u}+c \cot \phi & =\left(q_{E}+\gamma_{0} u\right) \cos \beta_{0}+c \cot \varphi^{\prime} \\
& =\tilde{\sigma}^{\prime}\left(1+\sin \phi \cos 2 \phi^{\prime}\right)
\end{aligned} \\
\tau_{u v}=-\left(q_{E}+\gamma_{0} u\right) \sin \beta_{0}=-\tilde{\boldsymbol{\sigma}}^{\prime} \sin \dot{s} \sin 2 \varphi^{\prime}
\end{gathered}
$$

上式から

$$
\frac{\left(q_{E}+\gamma_{0} u\right) \sin \beta_{0}}{\left(q_{E}+\gamma_{0} u\right) \cos \beta_{0}+c \cot \phi}=\frac{\sin \phi \sin 2 \phi^{\prime}}{1+\sin \phi \cos 2 \varphi^{\prime}}
$$

また式（25）の第1式からuが小なるとき，

$$
\left.\sin 2 \varphi^{\prime}=\sin 2 \phi_{0}^{\prime}+2 f u \cos 2 \varphi_{0}^{\prime}\right\}
$$$$
\left.\cos 2 \varphi^{\prime}=\cos 2 \varphi_{0}^{\prime}-2 f u \sin 2 \xi_{0}^{\prime}\right\}
$$

これらの值を式 (26.6) に代入すると, $f$ の近似值と して次式が得られる。

$$
f=\frac{1}{2} \frac{\gamma_{0}\left\{\sin \beta_{0}+\sin \phi \sin \left(\beta_{0}-2 \phi_{0}^{\prime}\right)\right\}}{c \cos \phi \cos 2 \phi_{0}^{\prime}+q_{E} \sin \phi \cos \left(\beta_{0}-2{\varphi^{\prime}}^{\prime}{ }^{\prime}\right)}
$$

次に式 (26.5) で $\tilde{\sigma}^{\prime}=\left(q_{E}+r_{0} u\right) \sin \beta_{0} /\left(\sin \phi \sin 2 \phi^{\prime}\right)$ であるから，これに式 (25) の第 2 式の $\widetilde{\sigma}^{\prime}$ と式 (26.7) の $\sin 2 \phi^{\prime}$ を代入することにより，次式をうる.

$$
g=\frac{\tilde{\gamma}_{0} \cos \beta_{0}+2 f \tilde{\sigma}_{0}^{\prime} \sin \phi \sin 2 \varphi_{0}^{\prime}}{1+\sin \phi \cos 2 \psi_{0}^{\prime}} \text {. }
$$

残余の未定係数を求めるために, 式 (26.4) の $\phi$, 式 (25)の $\phi^{\prime}$, 式 (24) の $\omega$ を式 (14) の第1式に代入す れば，uが小なるとき次の近似式がえられる.

$$
a_{2}=\omega_{1} A_{1}+B_{1}
$$

ここに

$$
\begin{aligned}
& A_{1}=\frac{2 \sin \left(\dot{\varphi}_{0}+\varphi_{0}^{\prime}+2 \omega_{0}\right)}{\left[\left(\sin \phi \sin \left(\phi_{0}^{\prime}-\phi_{0}^{\prime}\right)-\sin \left(\dot{\varphi}_{0}+\psi_{0}^{\prime}+2 \omega_{0}\right)\right]\right.} * \\
& \text { * } \frac{\left.\tan \omega_{0}-\tan \left(\alpha_{1}-\beta\right)\right\}}{4} \\
& B_{1}=\frac{f\left[\sin \phi \sin \left(\psi_{0}-\phi_{0}^{\prime}{ }^{\prime}\right)+\sin \left(\phi_{0}+\phi_{0}{ }^{\prime}+2 \omega_{0}\right)\right]}{\left[\sin \phi \sin \left(\phi_{0}-\phi_{0}{ }^{\prime}\right)-\sin \left(\phi_{0}+\psi^{\prime}{ }^{\prime}+2 \omega_{0}\right)\right]} * \\
& * \overline{\left.\tan \omega_{0}-\tan \left(\alpha_{1}-\beta\right)\right\}}
\end{aligned}
$$

同様に $\phi, \phi^{\prime}, \omega, \tilde{\sigma}, \tilde{\sigma}^{\prime}$ は不連続線上で式 (14) の第 2 の式を満足させるので, $v=c_{1} u$ とおくと, $b_{1}, b_{2}$ に関し て次の近似式が得られる.

$$
\begin{aligned}
\left(\widetilde{\boldsymbol{\sigma}}_{0}+b_{1} u\right. & \left.+c_{1} b_{2} u\right) \sin \left[2\left(\dot{\psi}_{0}+\omega_{0}\right)\right. \\
& +2 u\left[a_{2} c_{1}+\omega_{1}-a_{2} \tan \left(\alpha_{1}-\beta\right)\right] \\
= & \left(\widetilde{\boldsymbol{\sigma}}_{0}^{\prime}+g u\right) \sin \left[2\left(\phi_{0}^{\prime}+\omega_{0}\right)+2\left(\omega_{1}+f\right) u\right]
\end{aligned}
$$

上式で $u$ が小なる場合の関係式と，かつ $\tilde{\sigma}_{0} \sin 2\left(\psi_{0}\right.$ $\left.+\omega_{0}\right)=\tilde{\sigma}_{0}{ }^{\prime} \sin 2\left(\phi_{0}{ }^{\prime}+\omega_{0}\right)$ なる関係を用いると, 次式を らる。

$$
b_{1}+b_{2} \tan \omega_{0}=\omega_{1} D+a_{2} E_{1}+F_{1}
$$

$こ こ に$,

$$
\begin{aligned}
D_{1}= & \frac{2}{\sin 2\left(\phi_{0}+\omega_{0}\right)}\left[\tilde{\sigma}_{0}^{\prime} \cos 2\left(\dot{\varphi}_{0}^{\prime}+\omega_{0}\right)\right. \\
& \left.-\widetilde{\sigma}_{0} \cos 2\left(\phi_{0}+\omega_{0}\right)\right] \\
E_{1}= & -\frac{2}{\sin 2\left(\varphi_{0}+\omega_{0}\right)}\left[\tilde{\sigma}_{0}\left\{\tan \omega_{0}-\tan \left(\alpha_{1}-\beta\right)\right\}\right. \\
& \left.\cdot \cos 2\left(\phi_{0}+\omega_{0}\right)\right] \\
F_{1}= & \frac{2}{\sin 2\left(\phi_{0}+\omega_{0}\right)}\left[2 f \tilde{\sigma}_{0}^{\prime} \cos 2\left(\dot{\varphi}_{0}^{\prime}+\omega_{0}\right)\right. \\
& \left.+g \sin 2\left(\phi_{0}^{\prime}+\omega_{0}\right)\right]
\end{aligned}
$$

最後に $\phi, \tilde{\sigma}$ は次のすべり面の方程式を満足させなけ ればならない。

$$
\frac{d v}{d u}=-\tan (\phi \pm \mu)
$$

ここに，

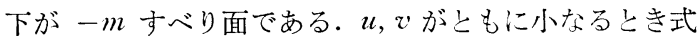
(24) の第 1 式の $\phi$ を上式に代入すると, 


$$
\frac{d v}{d u}=-\tan \left(\dot{\psi}_{0} \pm \mu\right)
$$

ここに複号の上が $+m$ すべり面，下が $-m$ すべり面 である.

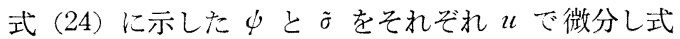
(26.14) を用いると次式をうる.

$$
\left.\begin{array}{l}
d \dot{\varphi}=\left\{a_{1}-a_{2} \tan \left(\phi_{0} \pm \mu\right)\right\} d u \\
d \tilde{\sigma}=\left\{b_{1}-b_{2} \tan \left(\dot{\phi}_{0} \pm \mu\right)\right\} d u
\end{array}\right\}
$$

すべり面に沿う応力式は次式で与えられる.

$$
\begin{aligned}
d \tilde{\sigma} \pm 2 \tilde{\sigma} \tan \phi d \varphi= & \frac{\gamma_{0}}{\cos \phi}\left[\cos \left(\beta_{0} \mp \phi\right) d u\right. \\
& \left.-\sin \left(\beta_{0} \mp \phi\right) d v\right] \ldots \ldots .
\end{aligned}
$$

ここに，上号が $+m$ すべり面，下号が $-m$ すべり面 である. 式 (26.15) を式 (26.16) に代入し， $+m$ すべ り面, $-m$ すべり面で整理し, 式 (26.3) の関係を用 い，かつすべり面は原点でも成立するので次式をうる.

$+m$ すべり面は,

$$
b_{1}-b_{2} \tan \left(\phi_{0}+\iota\right)-a_{2} G_{1}=I_{1}
$$

$-m$ すべり面は,

$$
b_{1}-b_{2} \tan \left(\psi_{0}-\mu\right)+a_{2} J_{1}=K_{1}
$$

ここに,

$$
\left.\begin{array}{l}
G_{1}=2 \widetilde{\sigma}_{0} \tan \phi\left\{\tan \left(\alpha_{1}-\beta\right)+\tan \left(\phi_{0}+\mu\right)\right\} \\
J_{1}=2 \widetilde{\sigma}_{0} \tan \phi\left\{\tan \left(\alpha_{1}-\beta\right)+\tan \left(\phi_{0}-\mu\right)\right\} \\
I_{1}=\frac{\gamma_{0}}{\cos \phi}\left[\cos \left(\beta_{0}-\phi\right)+\sin \left(\beta_{0}-\phi\right) \tan \left(\dot{\varphi}_{0}+\mu\right)\right] \\
K_{1}=\frac{\gamma_{0}}{\cos \phi}\left[\cos \left(\beta_{0}+\phi\right)+\sin \left(\beta_{0}+\phi\right) \tan \left(\phi_{0}-\mu\right)\right]
\end{array}\right\}
$$

式 (26.10), 式 (26.12)より $\omega_{1}$ を消去すると, 次式 をうる。

$$
b_{1}+b_{2} \tan \omega_{0}-a_{2}\left(\frac{D_{1}}{A_{1}}+E_{1}\right)=-\frac{B_{1} D_{1}}{A_{1}}+F_{1}
$$

以上の式から， $b_{1}, b_{2}, a_{2}$ を求めると,

$$
\begin{aligned}
& b_{1}=\frac{1}{J_{0}}\left|\begin{array}{ccc}
I_{1} & -\tan \left(\phi_{0}+\mu\right) & -G_{1} \\
K_{1} & -\tan \left(\phi_{0}-\mu\right) & J_{1} \\
-\frac{B_{1} D_{1}}{A_{1}}+F_{1} & \tan \omega_{0} & -\left(\frac{D_{1}}{A_{1}}+E_{1}\right)
\end{array}\right| \\
& b_{2}=\frac{1}{J_{0}}\left|\begin{array}{ccc}
1 & I_{1} & -G_{1} \\
1 & K_{1} & J_{1} \\
1 & -\frac{B_{1} D_{1}}{A_{1}}+F_{1} & -\left(\frac{D_{1}}{A_{1}}+E_{1}\right)
\end{array}\right| \\
& a_{2}=\frac{1}{J_{0}}\left|\begin{array}{ccc}
1 & -\tan \left(\phi_{0}+\mu\right) & I_{1} \\
1 & -\tan \left(\phi_{0}-\mu\right) & K_{1} \\
1 & \tan \omega_{0} & -\frac{B_{1} D_{1}}{A_{1}}+F_{1}
\end{array}\right|
\end{aligned}
$$

ここに,

$$
J_{0}=\left|\begin{array}{ccc}
1 & -\tan \left(\phi_{0}+\mu\right) & -G_{1} \\
1 & -\tan \left(\phi_{0}-\mu\right) & J_{1} \\
1 & \tan \omega_{0} & -\left(\frac{D_{1}}{A_{1}}+E_{1}\right)
\end{array}\right|
$$

第 4 境界值問題の解のために， $f, g$ を除く 7 つの倸 数が必要である.そのうち4つの係数は上述したように 求められる. 残りの $\omega_{1}, a_{1}, c_{2}$ はそれぞれ式 (26.10), 式 (26.3), 式 (26.2) から求められる.

ここで注意すべきことは，式（24）に示した 4 式のそ れぞれの左辺，右辺はいずれも無次元化された值を使用 することにある.したがって各係数はいずれも無次元量 でありこのために式中の $c$ と $r$ は，前述したように おいて計算を行い，また $q_{E}$ は $q_{E} / c$ とする.

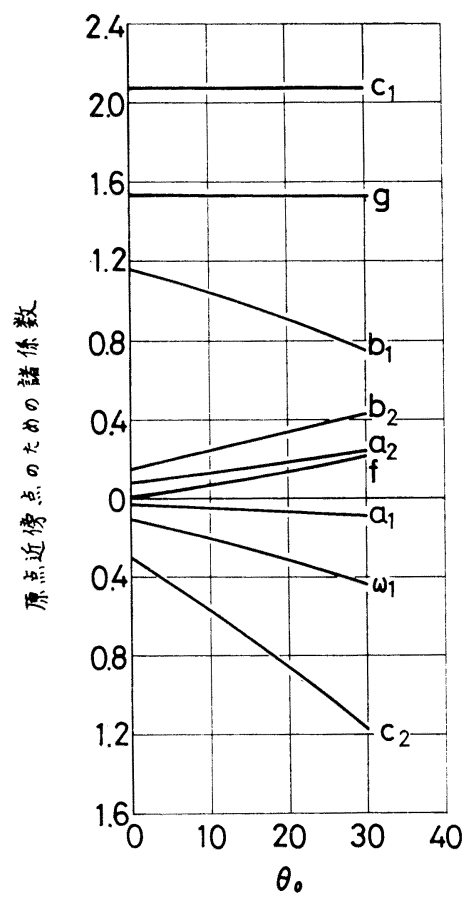

図一5 原点近傍の值を求めるための諸係数の一例

一例として, $\phi=20^{\circ}, \delta=0, c=1 \mathrm{t} / \mathrm{m}^{2}, \gamma=1 \mathrm{t} / \mathrm{m}^{3}, q_{i} c$ $=0, \alpha_{1}=20^{\circ}, \beta=0^{\circ}$ の場合の原点近傍の近似值を与える 各係数を, 係数 $f, g$ と一緒に示すと図一5のようにな る.これらの係数の值はいずれも壁面の值と不連続線上 の值 $\{$ 式 (14)\}を満足させることによって正しいことが わかる。

\section{(6) 漸 化 式}

図-4 の壁面 $O C$ 上の節点 $(i, j)$ をその近傍の節点 $(i, j-1)$ と壁面上の他の節点 $(i-1, j-1)$ 上り求沫 ための漸化式を以下に示す.

$$
\left.\begin{array}{rl}
u_{i, j} & =\frac{1}{I-E}\left[v_{i, j-1}-v_{i-1, j-1}-E u_{i, j-1}+I u_{i-1, j-1}\right] \\
v_{i, j} & =v_{i-1, j-1}+I\left(u_{i, j}-u_{i-1, j-1}\right) \\
\tilde{\sigma}_{i, j} & =\widetilde{\sigma}_{i, j-1}+2 \tilde{\sigma}_{i, j-1}\left(\phi_{i, j}-\psi_{i, j-1}\right) \tan \phi+r B D \\
\dot{\varphi}_{i, j} & =\psi_{0}
\end{array}\right\}
$$


ここに，

$$
\left.\begin{array}{l}
I=\tan \left(\alpha_{1}-\beta\right) \\
E=-\tan \left(\phi_{i, j-1}-\mu\right) \\
B=\frac{\cos \left(\beta_{0}+\phi\right)}{\cos \phi \cos \theta_{0}} \\
D=u_{i, j}-u_{i, j-1}-\left(v_{i, j}-v_{i, j-1}\right) \tan \left(\hat{\beta}_{0}+\dot{\phi}\right)
\end{array}\right\}
$$

次に不連続線 $O R$ 上の節点 $(i, j)$ をその近傍の節点 $(i-1, j)$ と壁面上の節点 $(i-1, j-1)$ から求めるため の漸化式を示す.

$$
\begin{aligned}
& u_{i, j}=\frac{v_{i-1, j-1}-v_{i-1, j}+F u_{i-1, j}-u_{i-1, j-1} \tan \omega_{i-1, j-1}}{F-\tan \omega_{i-1, j-1}} \\
& v_{i, j}=v_{i-1, j}+F\left(u_{i, j}-u_{i-1, j}\right) \\
& \varphi_{i, j}^{\prime}=\frac{1}{2 \widetilde{\sigma}_{i-1, j} \tan \phi+M_{i-1, j-1}}\left[\widetilde{\sigma}_{i-1, j}-\widetilde{\sigma}_{i-1, j-1}\right. \\
& +2 \tan \phi \widetilde{\sigma}_{i-1, j} \psi_{i-1, j}+\gamma A C \\
& +M_{i-1, j-1}\left(\psi_{i-1, j-1}+\psi_{i, j}^{\prime}-\psi_{i-1, j-1}^{\prime}\right) \\
& \left.-N_{i-1, j-1}\left(\widetilde{\sigma}^{\prime}{ }_{i, j}-\widetilde{\sigma}^{\prime}{ }_{i-1, j-1}\right)\right] \\
& \tilde{\sigma}_{i, j}=\tilde{\sigma}_{i-1, j}-2 \tilde{\sigma}_{i-1, j}\left(\psi_{i, j}-\psi_{i-1, j}\right) \tan \dot{\phi}+\gamma A C
\end{aligned}
$$

$$
\text { ここに }
$$

$$
\left.\begin{array}{l}
F=-\tan \left(\psi_{i-1, j}+\mu\right) \\
N_{i-1, j-1}=\frac{\sin 2\left(\phi_{i-1, j-1}^{\prime}+\omega_{i-1, j-1}\right)}{\sin 2\left(\psi_{i-1, j-1}+\omega_{i-1, j-1}\right)} \\
A=\frac{\cos \left(\beta_{0}-\phi\right)}{\cos \phi \cos \theta_{0}} \\
C=u_{i, j}-u_{i-1, j}-\left(v_{i, j}-v_{i-1, j}\right) \tan \left(\beta_{0}-\phi\right)
\end{array}\right\}
$$

また $\tan \omega_{i-1, j-1}, M_{i-1, j-1}$ はそれぞれ式 (17)，(20) の $\psi, \psi^{\prime}, \omega$ に下付き記号 $i-1, j-1$ を付して表わされ 万.

式 (27)，(29）を用いて計算を行らに当って，下付き 記号 $(i-1, j-1)$ の最初の值として, 原点の值 $\left(u_{0}, v_{0}\right.$, $\left.\tilde{\sigma}_{0}, \psi_{0}\right)$ をとる. また壁面上の節点を求めるための下付き 記号 $(i, j-1)$ の最初の值, 不連続線上の節点を求めるた めの下付き記号 $(i-1, j)$ の最初の值はいずれも前述し た原点近傍の近似值 $\left(u_{*}, v_{*}, \psi_{*}, \tilde{\sigma}_{*}, \omega_{*}\right)$ を採用する.

\section{4. 計算結果と考察}

\section{（1）特異点による計算結果の一例}

粘着力がなく，その強さを内部摩擦角のみに依存する 砂地盤の受働土圧は，直線分布であるが10)，粘性土地盤 の受働土圧は一般に曲線分布で与えられる. 以下に示す 計算では，基礎地盤面の傾角，あるいは壁面の傾角のい かんにかかわらず，壁の鉛直高さが 10 になるように計 算し,すべて無次元の值で示した. この無次元化に当っ $\tau, l$ (特性線長),$s$ (特性線応力) をそれぞれ $l=c / r$, $s=c$ とおき, $u^{\prime}=u / l, v^{\prime}=v / l, \sigma^{\prime}=\sigma / s, \tau^{\prime}=\tau / s$ で表わ した. また $c=1 \mathrm{t} / \mathrm{m}^{2}, r=1 \mathrm{t} / \mathrm{m}^{3}$ とおいたので，無次元 計算における漸化式は前述した漸化式をそのままの形で 使用できる.この無次元量から，たとえば， $c=2 \mathrm{t} / \mathrm{m}^{2}$ ，

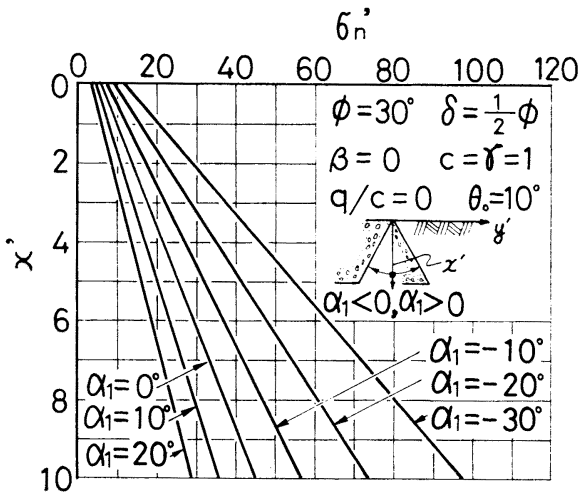

図一6 $\beta=0$ のとき， $\alpha_{1}$ による $\sigma_{n}{ }^{\prime}$ の変化 $\left(\hat{o}=0, \phi=30^{\circ}, \theta_{0}=10^{\circ}\right)$

$\gamma=1.6 \mathrm{t} / \mathrm{m}^{3}$ の土圧を求める場合には, $s=2 \mathrm{t} / \mathrm{m}^{2}, l=2$ i $1.6=1.25 \mathrm{~m}$ となるから，この $s$ と $l$ を用いて， $\sigma=$ $\sigma^{\prime} s, \tau=\tau^{\prime} s, u=u^{\prime} l, v=v^{\prime} l$ として, 応力と寸法を求め ればよい。

図一6 は $\phi=30^{\circ}, \delta=1 / 2 \cdot \phi, \beta=0, q / c=0, \theta_{0}=10^{\circ}$ の とき種々の傾角をもつ壁面に作用する垂直応力 $\sigma_{n}{ }^{\prime}$ の分 布を示している， $\alpha_{1}$ の值が小であるほど， $\sigma_{n}{ }^{\prime}$ の值は大 である. 壁面に沿うせん断応力の分布は示してないが， $\tau_{n t^{\prime}}=-\left(\sigma_{n}{ }^{\prime}+\cot \phi\right) \cdot \tan \delta$ で求められる.なおこの場合 のすべり線網の一例は $\alpha_{1}=-30^{\circ}, \alpha_{1}=0, \alpha_{1}=20^{\circ}$ につ いて図一7 に示した。

図一8 は地表面傾角 $\beta$ が変化したときの土圧分布の 比較を示す． $\beta$ が大きいほど， $\sigma_{n}{ }^{\prime}$ は大である。またす べり線網は 図一9 のようになる. $\left|\beta_{0}\right|>\phi$ のとき応力解
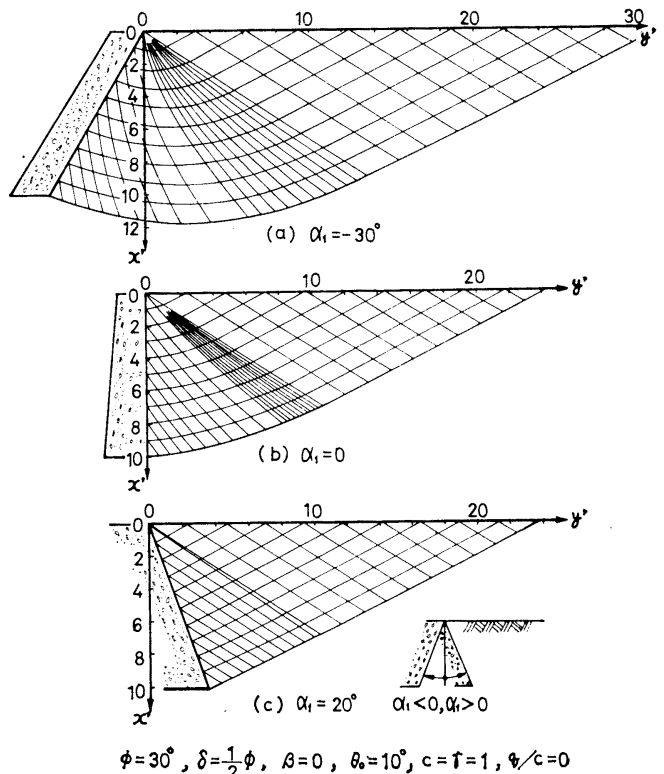

図一7 $\beta=0, \theta_{0}=10^{\circ}$ のときのすべり線網 


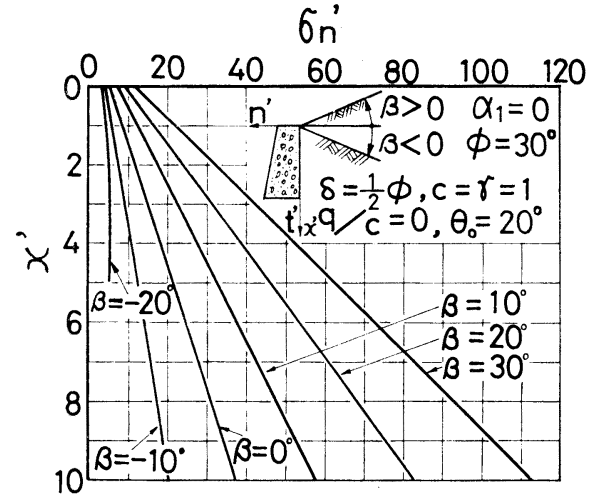

図一8 $\boldsymbol{a}_{1}=0$ のとき, $\beta$ による $\sigma_{n}{ }^{\prime}$ の変化 $\left(\delta=\frac{1}{2} \phi, \dot{\phi}=30^{\circ}, \theta_{0}=20^{\circ}\right)$

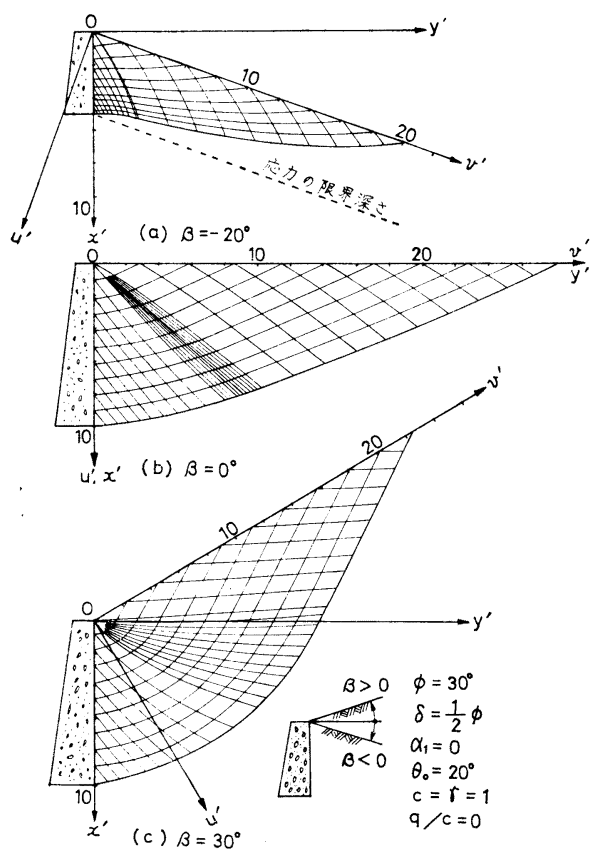

図一9 $\alpha_{1}=0, \theta_{0}=20^{\circ}$ のときのすべり線網

析の限界線9上り深いところでは計算が不可能である.

図一10 は鉛直壁で地表面が水平な条件で，地震合成 角 $\theta_{0}$ が変化した場合の土圧分布を比較したものである. 設計には $\theta_{0}>0$ の場合を考えればよい，この場合，す心゙ り線網の一番外枠の形を 図一11 に示した.

図一12 は同じく鉛直壁, 水平地盤で $\delta$ が変化した場 合の $\sigma_{n}{ }^{\prime}$ の変化を示した. $\delta$ が大きいほど $\sigma_{n}{ }^{\prime}$ は大で ある.またその場合のすべり線網の外枠の形を 図一13 に示した. 他の条件が同じで, 内部摩擦角が変化した場 合の $\sigma_{n}{ }^{\prime}$ の変化は図示していないが，内部摩擦角が大き Wほど $\sigma_{n}{ }^{\prime}$ は大である. 以上 $\sigma_{n}{ }^{\prime}$ の $\alpha_{1}, \beta, \theta_{0}, o, \phi の$ それぞれによる变化の様子は $\phi$ のみによる土の受働土

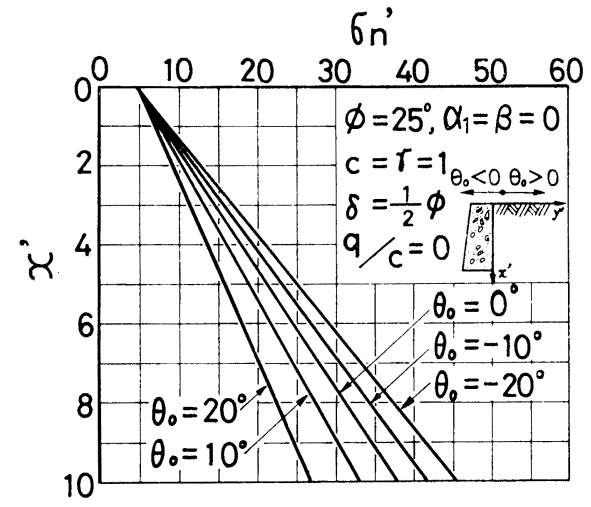

図一10 $\alpha_{1}=\beta=0$ のとき $\theta_{0}$ による $\sigma_{n}{ }^{\prime}$ の変化 $\left(\delta=\frac{1}{2} \phi, \phi=25^{\circ}\right)$

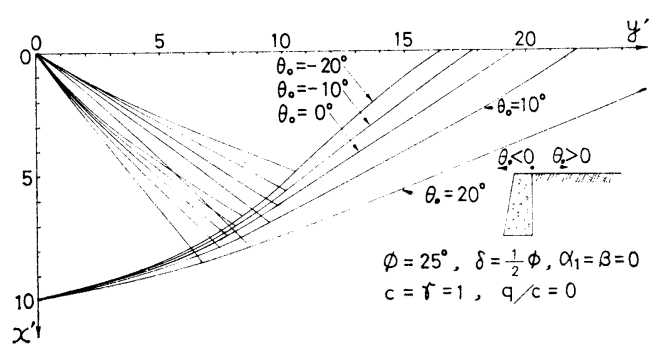

図一11 $a_{1}=\beta=0$ のとき $\theta_{0}$ によるすべり線網の外枠

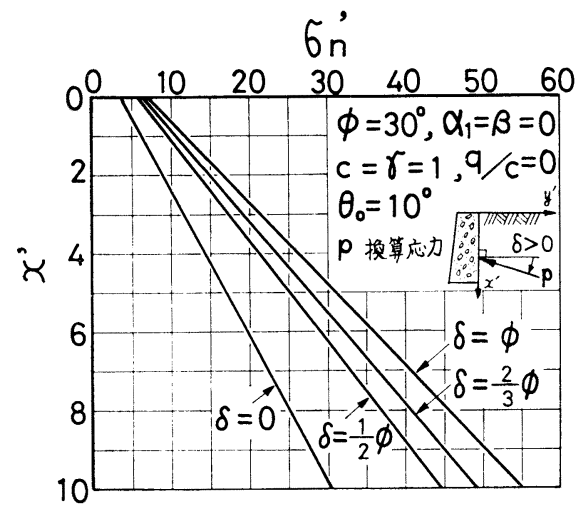

図一12 $\boldsymbol{\alpha}_{1}=\beta=0$ のとき $\boldsymbol{\delta}$ による $\sigma_{n}{ }^{\prime}$ の変化 $\left(\phi=30^{\circ}, \theta_{0}=10^{\circ}\right)$

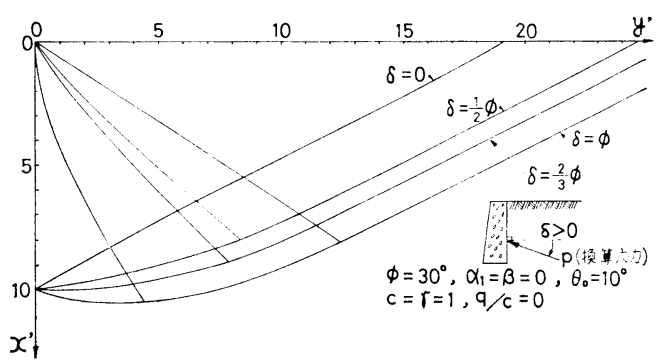

図一13 $a_{1}=\beta=0$ のとき $\delta$ によるすべり線網の外枠 
圧8),10)の場合と同じである.

\section{（2）特異点による計算結果の考 察}

筆者らは実用のために, 粘性土の 受働土圧を容易に算定できるよう に，数表で表わした. 前述したよう 汇 $\left|\beta_{0}\right|>\phi$ を除いては，土圧の分布 畆線分布とみなしうる。したがっ て壁面に作用する垂直土圧 $\sigma_{n}$ を次 式で表わした。

$$
\sigma_{n}=c \cdot K_{P c}+\gamma x K_{P_{\gamma}} \cdot
$$

上式で $c=r=1$ と書くと次の無 次元量で表わされる.

$$
\sigma_{n}{ }^{\prime}=K_{P c}+x^{\prime} K_{P_{r}}
$$

壁面に作用する垂直土圧合力 $Q$ は,

$$
\begin{aligned}
Q=\int_{0}^{H_{1}} \sigma_{n} d t & =\frac{1}{\cos \alpha_{1}} \int_{0}^{H} \sigma_{n} d x \\
& =\frac{1}{\cos \alpha_{1}}\left[c H \cdot K_{P c}+\frac{1}{2} ; H^{2} K_{P_{r}}\right]
\end{aligned}
$$

ここに $H_{1} \cos \alpha_{1}=H$ である.

壁面に沿うせん断力を $T$ とすれば,

$$
T=\int_{0}^{H_{1}} \tau_{n t} d t=-\left(Q+c \frac{H}{\cos \alpha_{1}} \cot \phi\right) \tan \delta
$$

このように地震時受働土圧合力は, $K_{P c}$ と $K_{P \gamma}$ の值 が明確であれば容易に算定できる.しかしながら実際に 数值計算した土圧分布は, わずかながら曲っているの ミ゙,この数值計算から求めた合力 $Q_{R}$ と直線分布として 求めた合力 $Q$ との関係を Lee らにならって次に示す記 号 $f$ で表わした.

$$
Q_{R}=f Q=f\left[\frac{1}{\cos \alpha_{1}}\left\{\frac{1}{2} \gamma H^{2} K_{P_{\gamma}}+c H K_{P c}\right\}\right] \cdots
$$

$f$ の值は壁高 $H$ により変化し, また $\alpha_{1}, \beta, \theta_{0}$ の各 值が小であるほど大である.

$K_{P c}$ は式 (31) より壁頂における垂直土圧 $\sigma_{n}$ を粘着 力 $c$ で除して求められる. $K_{P_{\gamma}}$ は次式で求められる.

$$
K_{P_{\gamma}}=\left[\sigma_{n}^{\prime}\left(x^{\prime}\right)-\sigma_{n}{ }^{\prime}\left(x^{\prime}=0\right)\right] / x^{\prime}
$$

ここに, $\sigma^{\prime}{ }_{n}\left(x^{\prime}\right)$ は壁面の深さ $x^{\prime}$ の位置における $\sigma_{n}{ }^{\prime}$ をあらわす. $K_{P_{\gamma}}$ は $x^{\prime}$ により多少変化するが, 筆者 らは $x^{\prime}=H^{\prime}=10$ として $K_{P \gamma}$ を求めた. $K_{P c}, K_{P_{\gamma}}$ の 值は一例として $\alpha_{1}=0$ の場合に表一 1 に, $\beta=0$ の場合 に 表一2 に示した. この 表一1 には不連続解による值 も示されている. 表一1 からわかるが, $\alpha_{1}=\beta=0, \delta=0$, $\theta_{0}=0$ の場合のみ $K_{P c}, K_{P \gamma}$ は Rankine 土圧による值 々一致する. この表に対応する $f$ の值として $\delta=1 / 2 \cdot \phi$, $\phi=25^{\circ}, \theta_{0}=10^{\circ}$ の場合についてのみ 図一14 に示した. この図によると, $\beta=-20^{\circ}$ を除いて, $H^{\prime}=10$ の場合

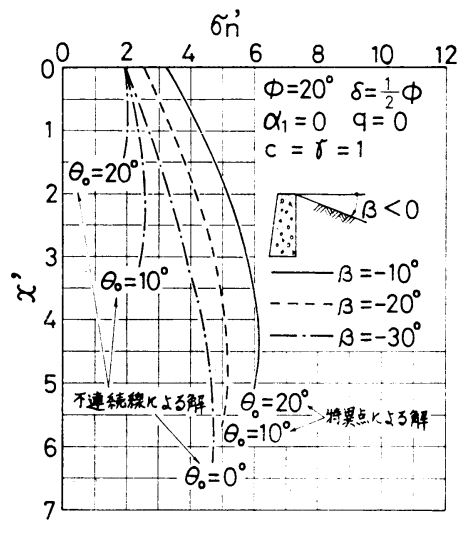

図一15 $\left|\beta_{0}\right|>\phi$ の場合の土圧分布の一例 $\left(\delta=\frac{1}{2} \phi, \phi=20^{\circ}\right)$

に，土圧分布を直線とみなした場合の誤差は，1.0\% 以 下であることがわかる. $\beta=-20^{\circ}$ は $\left|\beta_{0}\right|>\phi$ の場合に相 当し,この条件では受働土圧分布を直線としてあらわす ことができないことがわかる.したがって $\left|\beta_{0}\right|>\phi$ の場 合には， $\sigma_{n}$ の分布の一例を 図一15に示した。なおこの 図には, 次章に示寸不連続線の解による土圧分布も併記 されている.

\section{（3）不連続線による解法の結果と考察}

以下に示す不連続線による解法で, 原点近傍の解を求 める場合に, 式 $(24)$ に関連する $u_{*}{ }^{\prime}$ は $\left(\dot{\psi}_{0}{ }^{\prime}-\psi_{0}\right)$ の 值に応じて次の值をとった.

$$
\begin{aligned}
& \phi_{0}^{\prime}-\phi_{0}=10^{\circ} \sim 30^{\circ}, u_{*}{ }^{\prime}=0.01 \\
& \psi_{0}^{\prime}-\phi_{0}=40^{\circ} \sim 60^{\circ}, u_{*}{ }^{\prime}=0.1 \\
& \psi_{0}^{\prime}-\phi_{0}=70^{\circ} \sim 80^{\circ}, u_{*}=0.5
\end{aligned}
$$

ただし精度をあげるために，主として $u_{*}^{\prime}=0.01$ で計 算を行った場合が多い. $u_{*}^{\prime}$ が小であるほど, 精確な特 性線が得られるが, 計算に時間を要することになる。

不連続線の一例を 図一16 に示した. 図に示した不連 続線と地表面との間のすべり線網はモールの円を用いて 描いた ${ }^{11)}$.

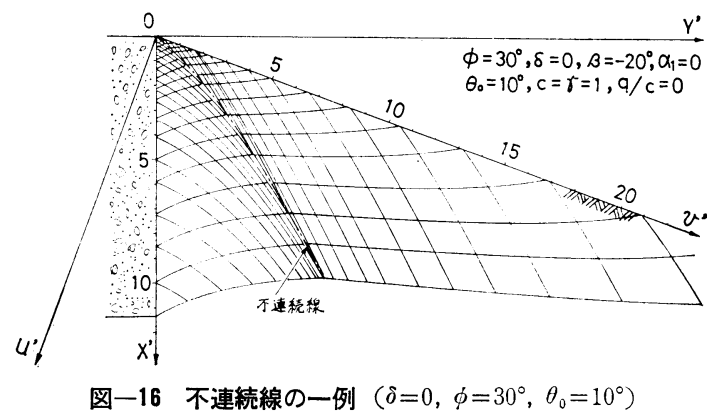




\begin{tabular}{|c|c|c|c|c|c|c|c|c|c|c|c|c|c|}
\hline \multirow{2}{*}{\multicolumn{2}{|c|}{ : }} & & \multicolumn{2}{|c|}{ 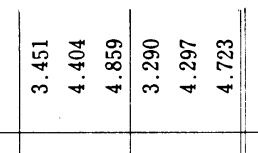 } & \multicolumn{2}{|c|}{ 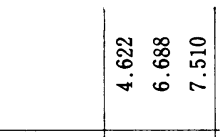 } & 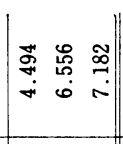 & 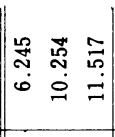 & 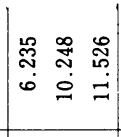 & $\mid$\begin{tabular}{lll}
$\mathbb{1}$ & 0 & 8 \\
\hdashline & 0 & 0 \\
0 & 0 & 9 \\
0 & $=$
\end{tabular} & $\mid \begin{array}{lll}\overrightarrow{0} & \overrightarrow{7} & g \\
0 & 0 \\
\infty & 0 & 0 \\
0 & 0 & 9\end{array}$ & 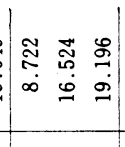 & 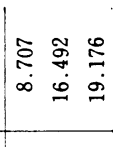 \\
\hline & & $\begin{array}{|lll|}* & * & \\
* & * & * \\
\end{array}$ & 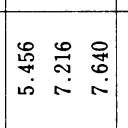 & 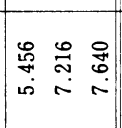 & $\mid \begin{array}{lll}* & * & * \\
* & * & *\end{array}$ & 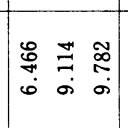 & 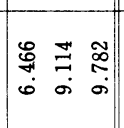 & 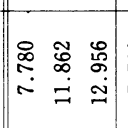 & 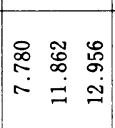 & 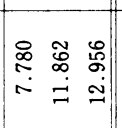 & 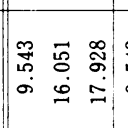 & 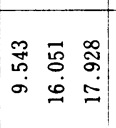 & 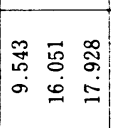 \\
\hline & $\mid \begin{array}{c}0 \\
-0 \\
0\end{array}$ & 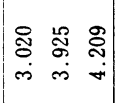 & 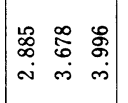 & 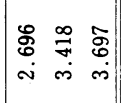 & 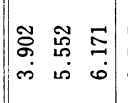 & 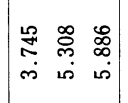 & 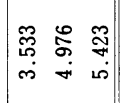 & $\left|\begin{array}{ccc}0 & 0 & \tilde{m} \\
0 & 0 & 0 \\
i n & \infty & 0 \\
\text { in } & \infty\end{array}\right|$ & 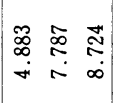 & 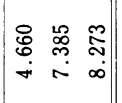 & 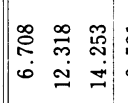 & 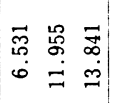 & 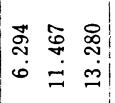 \\
\hline & |c & $\left|\begin{array}{ccc}\infty & 0 & 8 \\
\multirow{4}{*}{} & 0 & 0 \\
\hdashline & 0 & 0\end{array}\right|$ & 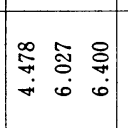 & 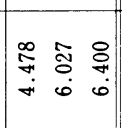 & 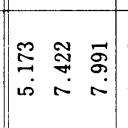 & 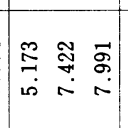 & 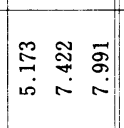 & 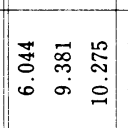 & $\mid \begin{array}{ccc}0 & \overrightarrow{0} & 0 \\
0 & 0 & 0 \\
0 & 0 & 0 \\
0 & 0 & 0 \\
& & 0\end{array}$ & 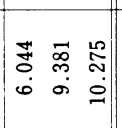 & 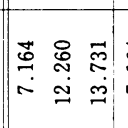 & 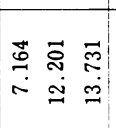 & 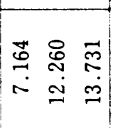 \\
\hline & $\mid \vec{c}$ & 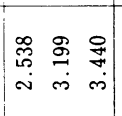 & 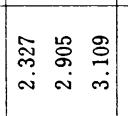 & 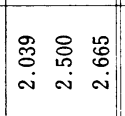 & 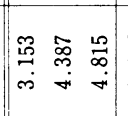 & 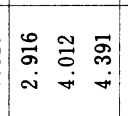 & 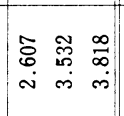 & 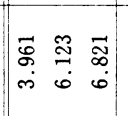 & 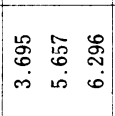 & 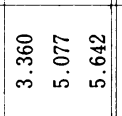 & $\left|\begin{array}{ccc}9 & 0 & 0 \\
0 & \infty & 0 \\
\text { in } & \infty & 0 \\
\text { in } & \infty & 0\end{array}\right|$ & 薄 & 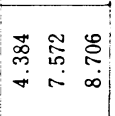 \\
\hline & $\approx$ & 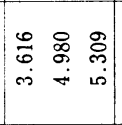 & 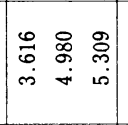 & 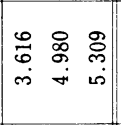 & 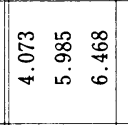 & $\left|\begin{array}{ccc}0 & 0 & \infty \\
0 & 0 & 0 \\
\hdashline & 0 & 0 \\
\dot{\sigma} & \omega & 0\end{array}\right|$ & $\left|\begin{array}{ccc}0 & 0 & \infty \\
0 & 0 & 0 \\
\dot{\gamma} & 0 & 0 \\
0 & 0 & 0\end{array}\right|$ & 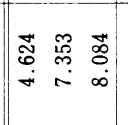 & 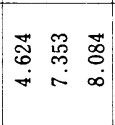 & 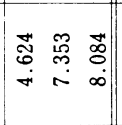 & 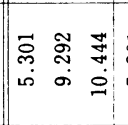 & 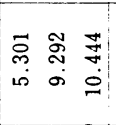 & 总 \\
\hline & $-\frac{1}{2}$ & 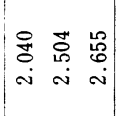 & 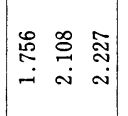 & 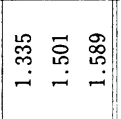 & 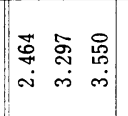 & 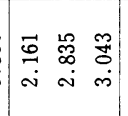 & 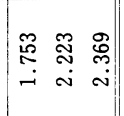 & 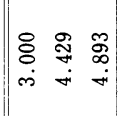 & 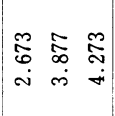 & 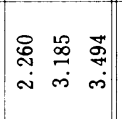 & 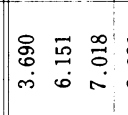 & 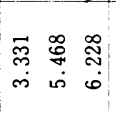 & 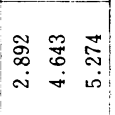 \\
\hline & 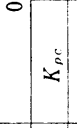 & 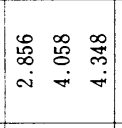 & 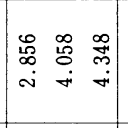 & 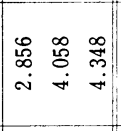 & 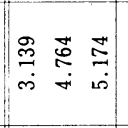 & 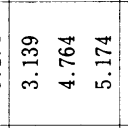 & 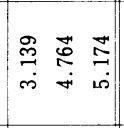 & 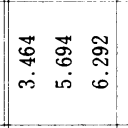 & 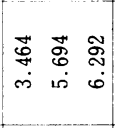 & 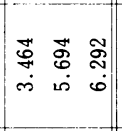 & 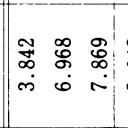 & 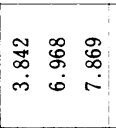 & 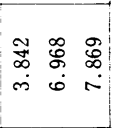 \\
\hline & 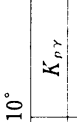 & 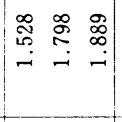 & 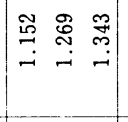 & $\begin{array}{ll}= & 2 \\
\dot{1} & \frac{1}{x} \\
\mathbb{x} & \underline{x}\end{array}$ & 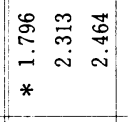 & 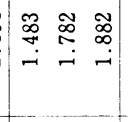 & $\frac{\infty}{1}$ & 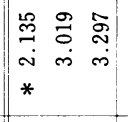 & 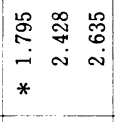 & 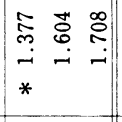 & 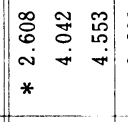 & 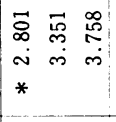 & 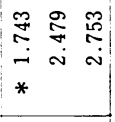 \\
\hline & $-<$ & 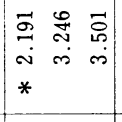 & 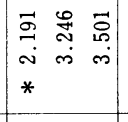 & $\mid$\begin{tabular}{lll|}
$*$ & $*$ & $*$ \\
$*$ & $*$ & $*$ \\
$*$ & & \\
\end{tabular} & 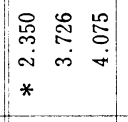 & 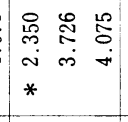 & \begin{tabular}{lll|}
$*$ & $*$ & $*$ \\
$*$ & $*$ & $*$ \\
$*$ & & \\
\end{tabular} & 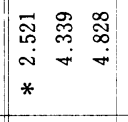 & 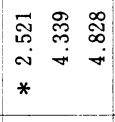 & 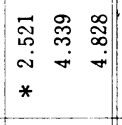 & 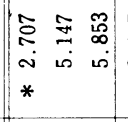 & 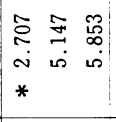 & $\begin{array}{ccc}0 & 0 & 0 \\
0 & 5 & 0 \\
N & 0 & 0 \\
* & 0 & 0 \\
*\end{array}$ \\
\hline & $x^{2}$ & 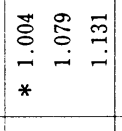 & $\begin{array}{ll}\approx & 0 \\
1 & 1 \\
\dot{\underline{x}} & \underline{\underline{x}}\end{array}$ & $\begin{array}{l}7 \\
\dot{x} \\
\underline{x}\end{array}$ & 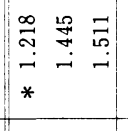 & $\begin{array}{l}\infty \\
\frac{1}{\underline{x}}\end{array}$ & & 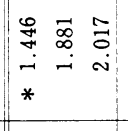 & 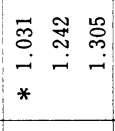 & $\begin{array}{l}9 \\
1 \\
\square\end{array}$ & 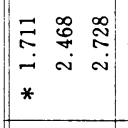 & 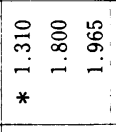 & $\begin{array}{l}8 \\
1 \\
1 \\
x\end{array}$ \\
\hline & 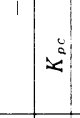 & 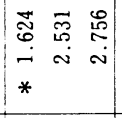 & $\mid$\begin{tabular}{lll|}
$*$ & $*$ & $*$ \\
$*$ & $*$ & $*$ \\
$*$ & & \\
\end{tabular} & $\mid$\begin{tabular}{lll|}
$*$ & $*$ & $*$ \\
$*$ & $*$ & $*$ \\
$*$ & & \\
\end{tabular} & 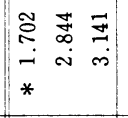 & $\mid \begin{array}{lll}* & * & * \\
* & * & * \\
* & & \end{array}$ & $\begin{array}{|lll|}* & * & * \\
* & * & * \\
* & & \\
\end{array}$ & 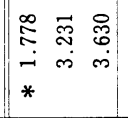 & 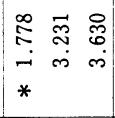 & $\mid$\begin{tabular}{lll|}
$*$ & $*$ & $*$ \\
$*$ & $*$ & $*$ \\
$*$ & & \\
\end{tabular} & 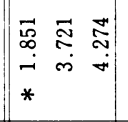 & 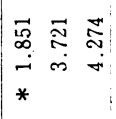 & $\begin{array}{lll}* & * & * \\
* & * & * \\
* & & \end{array}$ \\
\hline & & $\begin{array}{ll}7 & 2 \\
1 & 1 \\
\underline{x} & \frac{1}{x}\end{array}$ & $\begin{array}{ll}= & 2 \\
1 & 1 \\
\mathbf{x} & \mathbf{1}\end{array}$ & 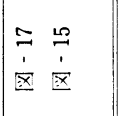 & 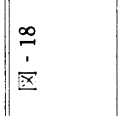 & $\begin{array}{l}\stackrel{\infty}{\rightarrow} \\
\dot{\square}\end{array}$ & $\begin{array}{l}\infty \\
\dot{1} \\
\dot{\Xi}\end{array}$ & $\left|\begin{array}{lll}\mathscr{x} & 0 & 0 \\
0 & 8 & 0 \\
0 & 0 & 0 \\
* & 0 & - \\
* & * & \end{array}\right|$ & $\begin{array}{l}9 \\
\dot{1} \\
\mathbf{x}\end{array}$ & $\frac{9}{1}$ & 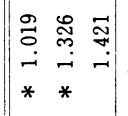 & $\begin{array}{l}\text { Dิ } \\
\dot{⿱ 亠 乂}\end{array}$ & $\begin{array}{l}\stackrel{8}{a} \\
\underline{\underline{x}}\end{array}$ \\
\hline & ల్ల & $\begin{array}{lll}* & * & * \\
* & * & * \\
* & * & *\end{array}$ & $\mid \begin{array}{lll}* & * & * \\
* & * & * \\
* & * & *\end{array}$ & \begin{tabular}{|lll||}
$*$ & $*$ & $*$ \\
$*$ & $*$ & $*$ \\
$*$ & $*$ & $*$ \\
\end{tabular} & $\left|\begin{array}{lll}* & * & * \\
* & * & * \\
* & * & *\end{array}\right|$ & $\left|\begin{array}{lll}* & * & * \\
* & * & * \\
* & * & *\end{array}\right|$ & $\mid$\begin{tabular}{lll|}
$*$ & $*$ & $*$ \\
$*$ & $*$ & $*$ \\
$*$ & $*$ & $*$
\end{tabular} & 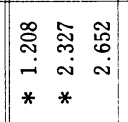 & $\begin{array}{lll}* & * & * \\
* & * & * \\
* & * & \end{array}$ & $\begin{array}{lll}* & * & * \\
* & * & * \\
* & * & \end{array}$ & 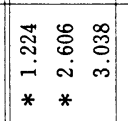 & \begin{tabular}{lll|}
$*$ & $*$ & $*$ \\
$*$ & $*$ & $*$ \\
$*$ & $*$ &
\end{tabular} & $\left|\begin{array}{lll}* & * & * \\
* & * & * \\
* & * & \end{array}\right|$ \\
\hline & & 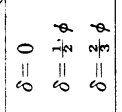 & 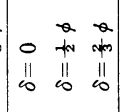 & 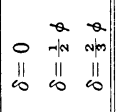 & $\left|\begin{array}{ccc} & -a & 2 \\
0 & -1+\infty & -\infty \\
11 & 11 & 11 \\
0 & 10 & \infty\end{array}\right|$ & 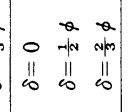 & 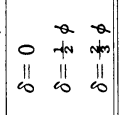 & 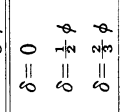 & 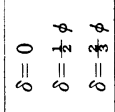 & 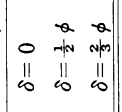 & $\left|\begin{array}{ccc} & -a & -a \\
0 & -1+\infty & 0 \\
11 & 11 & 11 \\
0 & 10 & \infty\end{array}\right|$ & 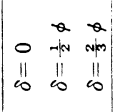 & $\left|\begin{array}{ccc}-2 & -2 \\
0 & -7 N & n+\infty \\
11 & 11 & \| 1 \\
0 & 0 & 0\end{array}\right|$ \\
\hline & $\infty^{\circ}$ & $\therefore$ & $\therefore$ & i் & $\therefore$ & $\dot{9}$ & : & 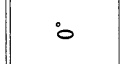 & $\therefore$ & : & $\therefore$ & $\stackrel{\circ}{\circ}$ & ๙ั \\
\hline & & & స & & & ํำ & & & i & & & & \\
\hline
\end{tabular}




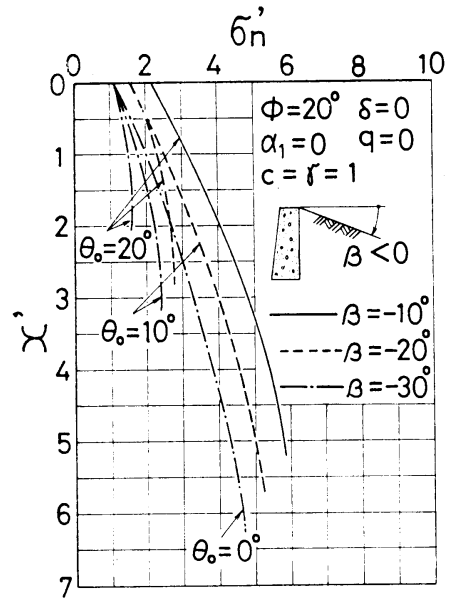

図一17 $\left|\boldsymbol{\beta}_{0}\right|>\boldsymbol{\phi}$ における不連続線で 求めた $\boldsymbol{\sigma}_{n}{ }^{\prime}$ の一例 (その $1, \delta=0, \phi=20^{\circ}$ )

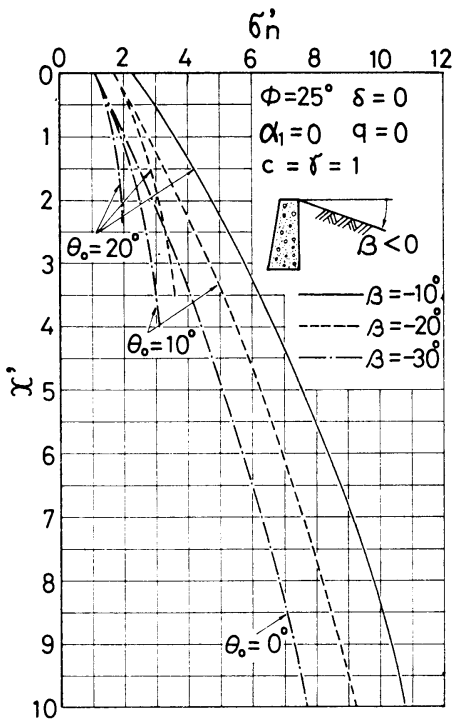

図一18 $\left|\beta_{0}\right|>\phi$ における不連続線で 求めた $\sigma_{n}^{\prime}$ の一例 (その $2, \delta=0, \phi=25^{\circ}$ )

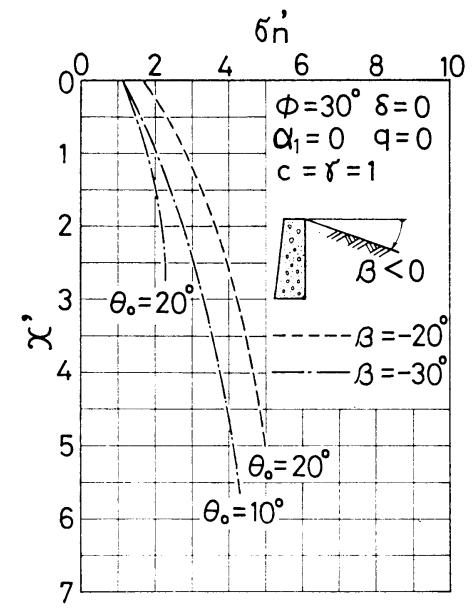

図一19 $\left|\beta_{0}\right|>\phi$ における不連続線で 求めた $\boldsymbol{\sigma}_{n}{ }^{\prime}$ の一例 (その $3, \delta=0, \dot{\phi}=30^{\circ}$ )

図一17，18，19，20 は， $\delta=0$ で $\phi$ をそれぞれ $20^{\circ}$, $25^{\circ}, 30^{\circ}, 35^{\circ}$ に変化させた場合, 不連続線を用いて求め た $\sigma_{n}{ }^{\prime}$ の分布を示寸. これらは表一1 に示した $K_{P c}$, $K_{P_{r}}$ に分解できない場合の一例である.

不連続線の解法が可能な条件は式 (13) に示される. 原点近傍の点から出発して, 次第に深いところにすべり 線を描くときに， $\psi$ の值は $\psi^{\prime}$ の值に接近してくる. $\phi$

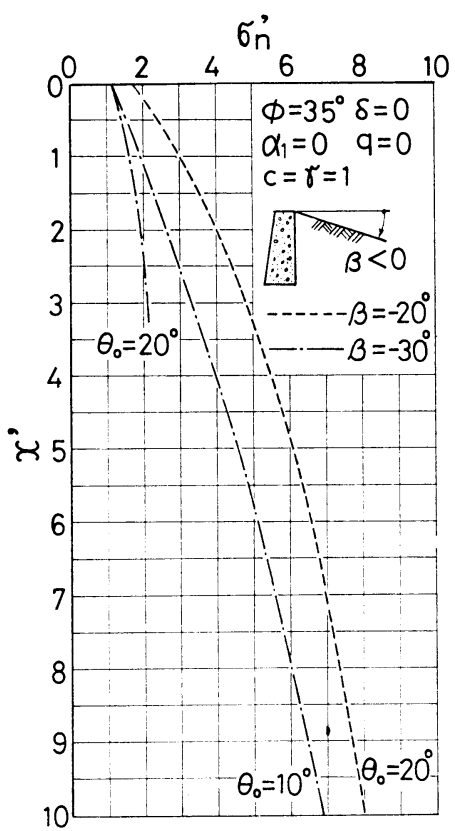

図一20 $\left|\boldsymbol{\beta}_{0}\right|>\phi$ における不連続線て 求めた $\boldsymbol{\sigma}_{n}{ }^{\prime}$ の一例

(その $4, \delta=0, \phi=35^{\circ}$ ) $\fallingdotseq \phi^{\prime}$ になると,

図一4に示した十 $m$ すべり面と不連 続線の交点が求め られないか, ある いは所定の深さの 位置よりもはるか に深い位置でのみ

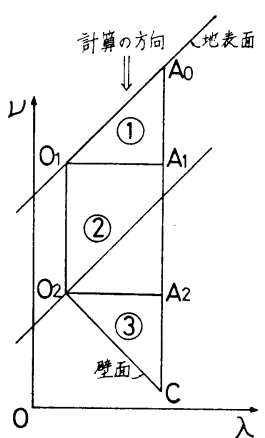

図一21（a）特異点の解を 強行する場合 の計算の説明
表一2 $\boldsymbol{\beta}=\mathbf{0}, \boldsymbol{\alpha}_{1}$ を変化させたときの $\boldsymbol{K}_{P c}, \boldsymbol{K}_{P_{\gamma}}\left(\delta=\frac{1}{2} \phi\right)$

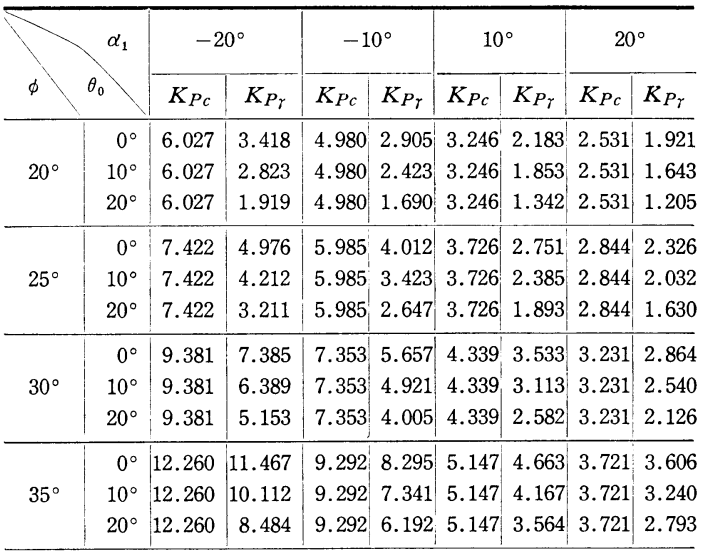

求められることになる，したがって，原点における $\psi_{0}$

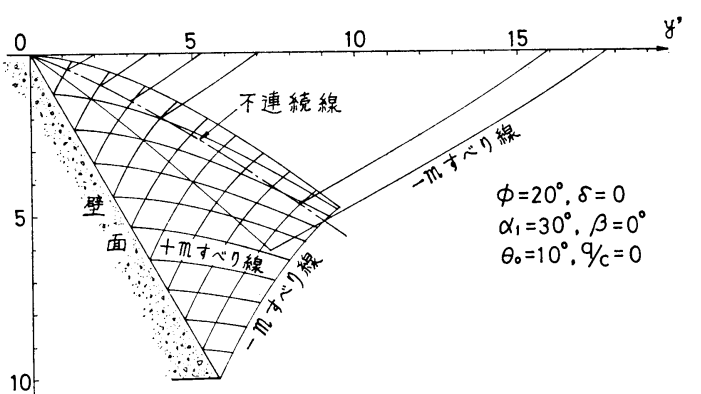

図一21（b）不連続線の条件に対して，特異点の解を 強行した場合のすべり線網 $\left(\alpha_{1}=30^{\circ}, \beta=0, \delta=0, \phi=20^{\circ}, \theta_{0}=10^{\circ}\right)$ 
の值と $\psi_{0}{ }^{\prime}$ の值が接近していると, 任意の壁長の土圧を 正確に求めることができない，そこで筆者らは，式(13) を満足させるにもかかわらず，領域が 図一21（a）のよ うに写像されるものと仮定して, 地表面から壁面に向か って, 逐次 Cauchy, Goursat, 混合境界值問題を解く ことにした.

図一21 (b) はこのように特異点の解を強行して求め たすべり線網である.この図から領域 (1) と (3) が重なり 合っていることがわかる. 重複した部分の一点鎖線は, 不連続線の解法から求めた不連続線を描いたものであ る.この不連続線は詳細に検討すると, 領域 (1) と領域 (3)のそれぞれの $-m$ すべり線の交点を原点から逐次結 んだ曲線に一致する.このことから, 不連続線上の応力

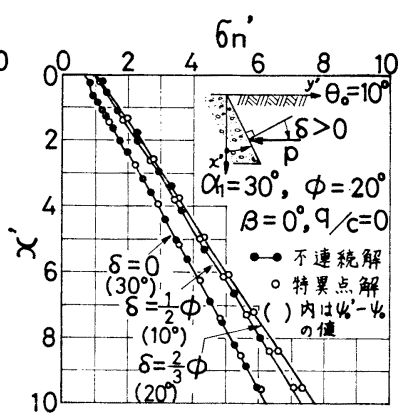

図一22 不連続線と特異点の解法による $\boldsymbol{\sigma}_{n}{ }^{\prime}$ の比較（その1）

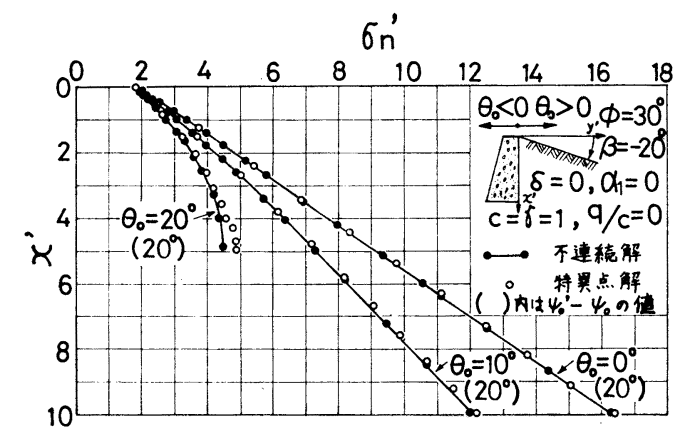

図一23不連続線と特異点の解法による $\sigma_{n}{ }^{\prime}$ の比較 (その 2)

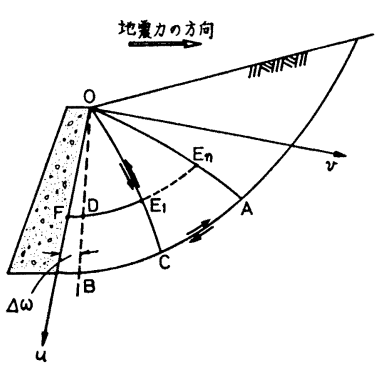

(a)

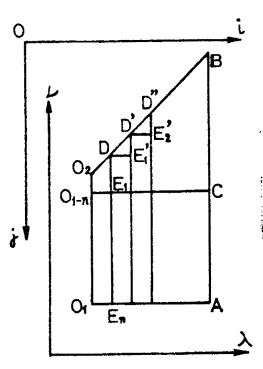

(b)
図一24 $\delta=\phi$ の場合, 壁面から地表面に向かって 計算を進める方法
は簡単には算定できないが，不連続線を有する場合のす ベり線網の概略は特異点の解法を強行しても知ることが できる. 地盤面の傾角 $\beta$, 壁摩擦角 $\delta$, 地震合成角 $\theta_{0}$ を 変化させた場合の, 上述した両計算法による $\sigma_{n}$ の比較 を図一22，23 に示した. また各図に $\phi_{0}{ }^{\prime}-\phi_{0}$ の值を括 孤内に示した. これらの図面によると, 両方法から求め た受働土圧の分布はよく一致している. 以上のすべり線 網と土圧分布の比較から不連続線による解法が不可能な ときはもちろん， $\phi_{0}{ }^{\prime}-\phi_{0}$ がかなりに大きな值でも，実 用の籁囲内で特異点の解を用いることが許される.

従来行ってきた不連続線の解法は, Lee ら ${ }^{7}$ が行った ように, 原点近傍では $r=0$ とし, すべり線ならびに不 連続線は直線として, 不連続線上の原点に近い第 1 点を 求めた.この点より深くなると $r \neq 0$ と考え, す べり線に沿うて数值積分を行い, 逐次深いところ の不連続上の值を決定した．しかしながら，この 方法では不連続線を試行法で求めることになり, 筆者らの行った第 4 境界值問題を解くことよりも はるかに計算がやっかいとなる. Lee らの上述の 解法の結果は壁面条件が異なるために, 筆者らの 結果と比較することはできなかった.

\section{5. 厳 密 解}

\section{（1）壁面から地表面に向かって逐次計算して土圧を 求める方法}

Sokolovski の特異点の解による土圧の算定では, 地 表面から壁面に向かって計算を進め, また計算の精度を あげる手段として，差分法における分割数を增した.し かしながら電子計算機の容量から, それほど数多くの分 割数を採用することはできない，そのために筆者らは計 算の精度をあげるために, 壁面から地表面に向かって計 算を進める方法を開発し, これから得た土圧と, 前述し た地表面から逐次計算して求めた土圧の平均值をもっ て，5.(2)に述べるよらにより正しい土圧とした.ここ では筆者らが開発した壁面から地表面に向かって計算し て壁面土圧を求める方法を, $\delta=\phi$ の場合について示す. $\delta=\phi$ では擁壁の土圧は, ほとんど特異点の解で求めら れる.

まずSokolovski が示したように, 壁面に沿うて $u$ 軸

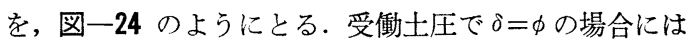
壁面 ( $u$ 軸) は $+m$ すべり面の包絡線となり, モール の円からわかるように, $\phi=-\mu$ となる.

この新しい座標で表わした塑性基本式に含まれる $+m$ すべり面の式に対して, 壁の近傍で $\cos (\psi+\mu)=1, \sin$ $(\psi+\mu)=\psi+\mu$ とおき, さらに $\tilde{\sigma}$ と $\phi$ の $u$ 軸に沿う 
変化は, 壁面上の変化とみなして, 次のようにおく, $\partial \phi / \partial u=0, \tilde{\sigma}=\tilde{\sigma}(u), \partial \tilde{\sigma} / \partial u=\tilde{\sigma}^{\prime}(u), こ こ に \tilde{\sigma}(u)$ は壁 面に沿う $\tilde{\sigma}$ を表わす. そのようにおくと, +mすべり 面は壁の近傍で次式で表わされる.

$$
\begin{aligned}
& {\left[\frac{\partial \tilde{\sigma}}{\partial v}+2 \widetilde{\sigma}(u) \tan \phi \frac{\partial \psi}{\partial v}\right](\phi+\mu)} \\
& \quad+r_{0} \frac{\cos \left(\alpha_{0}-\phi\right)}{\cos \phi}-\tilde{\sigma}^{\prime}(u)=0
\end{aligned}
$$

ここに受働土圧の場合に $\alpha_{0}=\alpha_{1}-\theta_{0}$ である. また $-m$ すべり面に関して，壁の近傍で，

$$
\cos (\phi-\mu)=\sin \phi, \sin (\phi-\mu)=-\cos \phi
$$

とおくと, 次のように積分される.

$$
\tilde{\sigma}-2 \tan \phi \tilde{\sigma}(u) \phi+f(u)=0
$$

$v=0$ では $\phi=-\mu, \tilde{\sigma}=\tilde{\sigma}(u)$ であるから

$\tilde{\sigma}=\tilde{\sigma}(u)[1+2(\phi+\mu) \tan \phi]$

式 (36)，(37）を連立させて求めた次式は壁の近傍の фを表わすことになる。

$$
(\dot{\varphi}+\mu)^{2}=\frac{\cot \dot{\phi}}{2 \widetilde{\sigma}(u)}\left[\tilde{\sigma}^{\prime}(u)-\gamma_{0} \frac{\cos \left(\alpha_{0}-\phi\right)}{\cos \phi}\right] v .
$$

壁の近傍で $+m,-m$ すべり面は次式で与えられる.

$$
\left.\begin{array}{l}
\frac{d v}{d u}=-(\phi+\mu) \\
\frac{d v}{d u}=\cot \phi-\frac{\phi+\mu}{\sin ^{2} \phi}
\end{array}\right\} .
$$

計算の方法を説明するために，まず図一24(a) の原 点を通り, 壁面に微小な角度 $\Delta \omega$ だけ傾く直線 $O B$ を 引く、壁面上に任意の点 $F$ をとり，この点を通る $-m$ すべり面の $O B$ 線ならびに $O C$ 線との交点をそれぞれ

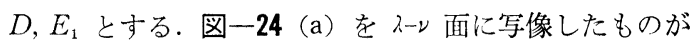
(b) 図である.いま漸化式（8）を使用するために， $E_{1}$ 点の 4 值の下付き記号を $(i, j)$ とおくと, $O_{1-n}$ 点, $D$ 点の 4 值の下付き記号はそれぞれ $(i-1, j),(i, j-1)$ で表わされる. 節点 $O_{1-n}$ の $\tilde{\sigma}$ と $\phi$ との関係は, 新し い座標に関連して次式で表わされるから,この 4 值は容 易に決定される.

$$
\begin{aligned}
\widetilde{\sigma}= & p^{\prime} \frac{\cos \delta^{\prime}+\sqrt{\cos ^{2} \overline{\delta^{\prime}}-\cos ^{2} \bar{\phi}}}{\cos ^{2} \phi^{\prime}} \\
& \times \exp \left[\left\{-\delta^{\prime}+\Delta^{\prime}+2\left(\beta-\alpha_{1}\right)+\pi+2 \psi\right\} \tan \phi\right] \cdots(40)
\end{aligned}
$$

$p^{\prime}$ は裏込め天端面の等分布載荷重を換算荷重で表わ したもの, $\phi$ は $O_{2}$ の $\phi$ に接近させた值をとる. した がっていま節点 $D$ の 4 值が決定されれば, 節点 $E_{1}$ の 4 值は式 (8) で $\beta_{0}$ の代わりに $\alpha_{0}$ とおいた漸化式から求 められる.

節点 $D$ の 4 值に関して, 次のように求められる. ま ず式 (39) で $\phi=-\mu$ とおくと, $-m$ すべり面 $F D$ は,

$$
u_{i, j-1}=u_{\omega}+v_{i, j-1} \tan \phi
$$

これと直線 $O B$ の条件から, $F$ 点の座標を $\left(u_{w}, 0\right)$ とすれば， $D$ 点の座標は,

$$
\left.\begin{array}{l}
u_{i, j-1}=\frac{u_{w}}{1-\tan \phi \tan \Delta \omega} \\
v_{i, j-1}=\frac{u_{w} \tan \Delta \omega}{1-\tan \phi \tan \Delta \omega}
\end{array}\right\} .
$$

次に式 (41) の $v_{i j-1}$ を式 (38) に代入し， かつ壁面 上の $u_{w}$ 点における $\tilde{\sigma}(u)$ を仮定すると, $D$ 点の $\psi_{i, j-1}$ は式 (38) より, $D$ 点の $\tilde{\sigma}_{i, j-1}$ は式 (37) 加ら求めら れる.

このようにして, $-m$ すべり面 $F D E_{1}$ の延長に沿う て, 式 (8) と同形の漸化式を用いて, 各節点の 4 值が 逐次決定される.

ここで, $O A$ 線上の $E_{n}$ が次に示す新しい座標 $(u, v)$ に関する $\phi, \tilde{\sigma}$ と一致するまで, $\tilde{\sigma}(u)$ を変えて, 計算 を繰り返して，正しい $\tilde{\sigma}(u)$ を求める.

$$
\begin{gathered}
u_{1}=u \cos \left(\beta-\alpha_{1}\right)+v \sin \left(\beta-\alpha_{1}\right) \\
\tan \delta^{\prime}=\frac{\left(q_{E}+\gamma_{0} u_{1}\right) \sin \beta_{0}}{\left(q_{E}+\gamma_{0} u_{1}\right) \cos \beta_{0}+c \cot \phi} \\
2 \phi=-\pi+\delta^{\prime}-\Delta^{\prime}-2\left(\beta-\alpha_{1}\right) \\
\text { ここに } \begin{aligned}
\sin \Delta^{\prime}=\sin \delta^{\prime} / \sin \phi, \beta_{0}=\beta-\theta_{0} \\
\tilde{\sigma}=\frac{\left[\left(q_{E}+\gamma_{0} u_{1}\right) \cos \beta_{0}+c \cot \phi\right]}{\cos \delta^{\prime} \cos ^{2} \phi} * \\
\left.\cos ^{2} \delta^{\prime}-\cos ^{2} \phi\right]
\end{aligned}
\end{gathered}
$$

この場合 $O A$ 線上で $\phi$ だけ一致させれば $\tilde{\sigma}$ も一致 する. なお, $\delta \neq \phi$ を壁面側から計算するときは, 前章 までに述べた $u-v$ 座標によって壁面の $\tilde{\sigma}(u)$ 在求めれ ばよい.

\section{(2) 峳密な $\boldsymbol{K}_{P r} 亡 \boldsymbol{f}$}

図一25 は分割数の増加に伴って, $K_{P r}$ の值がどんな

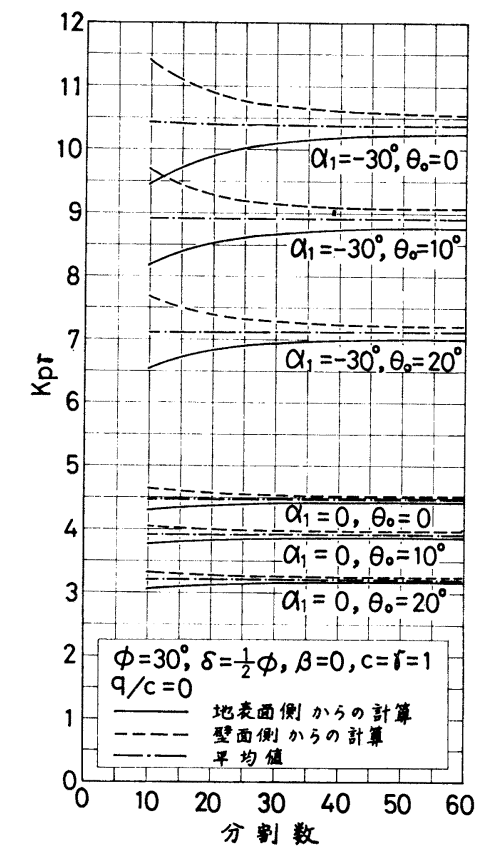

図一25 差分法の分割数による $K_{P_{\gamma}}$ の比較 $\left(\delta=\frac{1}{2} \phi, \phi=30^{\circ}, \beta=0\right)$ 
変化をするかを実線と点線で示した．

図より地表面側からの計算法（実線）では，分割数が 増加すると，土圧功大きくなる．この増加の割合は，10 分割から 20 分割にかけて急に大きくなり，20 分割以上 の分割では大きさの変化がゆるくなっている．筆者らの 計算では，通常 20 分割で地表面から行った．その理由 は分割数をこれ以下（たとえば 10 分割）にすると，後 述する厳密なる計算から得られた土圧分布と異なった分 布が得られるためである。

次に壁面側からの計算結果について考察すると, 図一 25 に点線で示すように, 分割数の増加によって, $K_{P \gamma}$ す なわち土圧は小さくなる。土圧の減少の割合は, やはり 10 分制ないし 20 分割が急である. したがって，図一25 から，地表面側と壁面側から行って得たそれぞれの $K_{P \gamma}$ は，分割を多くすると等しくなってくることが予想され る.しかしながら筆者らの数值計算では, 最大 60 分割 までしか，分割することができない。そのために壁面と 地表面からそれぞれ求めた $K_{P_{r}}$ を一致させることはで きない. いま各分割数ごとに，両方法による $K_{P \gamma}$ の平 均值を求めて図示すると, 図一25に示した一点鎖線で 表わさ机る.すなわちこの平均值は分割数によらない で，ほぼ一定の值をとることがわかる．分割数を 60 分 割よりもさらに増加させれば, 両方法による $K_{p_{r}}$ は, こ の平均值に収束するように考えられるので, この平均值 を稂密解亡した，なおすべり線も図一26に示すように， それぞれの計算值の平均值に収束する。

数值計算で得られる土圧合力と, 土圧を直線分布とし たときの土圧合力の比 $f$ が，分割数によってどのよう に変化するかを 図一27 に示した。実線で示した地表面 から計算した $f$ の值は，分割数が増すにしたがって大 きくなる．点線で示した壁面側から計算した $f$ の值は, 分割数が増加するにしたがい次第に小さくなる.このよ らに $f$ の值も $K_{P \gamma}$ と同様な傾向があることから，こ の $f$ の值も分割数ごとに壁面からの值と地表面からの

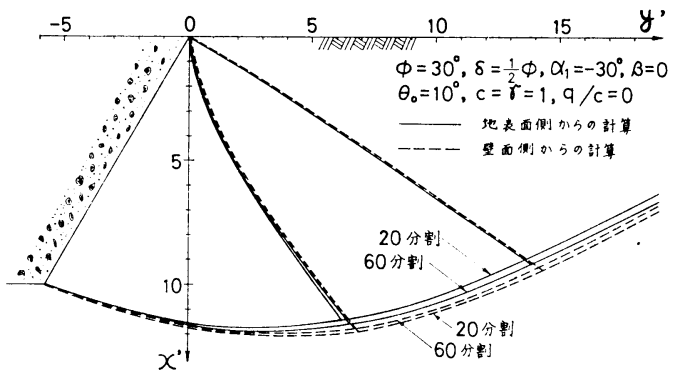

図一26地表面ならびに壁面からそれぞれ計算した 場合のすべり線の比較 $\left(\delta=\frac{1}{2} \dot{\phi}, \phi=30^{\circ}, \alpha_{1}=-30^{\circ}, \beta=0\right)$
值を平均した. この $f$ の平均值は図に示したように分 割数によらず，一点鎖線で代表されるということは特筆 すべきことである. 悠密な $f$ の值はこの場合, 地表面 から計算した場合の 20 分割に対して, $H^{\prime}=2$ で最大 3 $\%$ も大き. 以下厳密な計算值を基本にして, それとの 比較を行ら.

a) 㛜密な $K_{P r}$ と地表面 20 分割の $K_{P_{r}}$ の比較

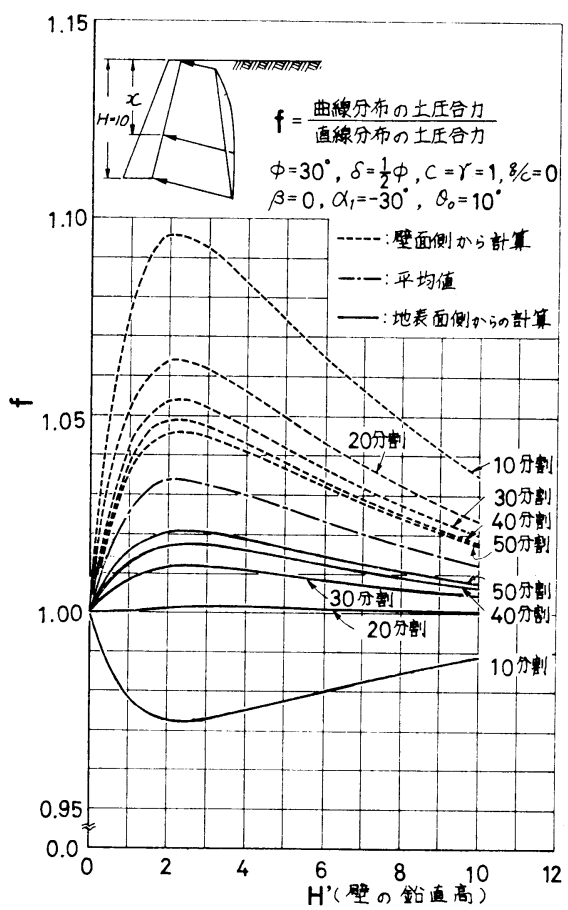

図一27 差分法の分割数による $\boldsymbol{f}$ の比較（点線：地表面か らの計算，実線：壁洏からの計算，鏫線：平均值）

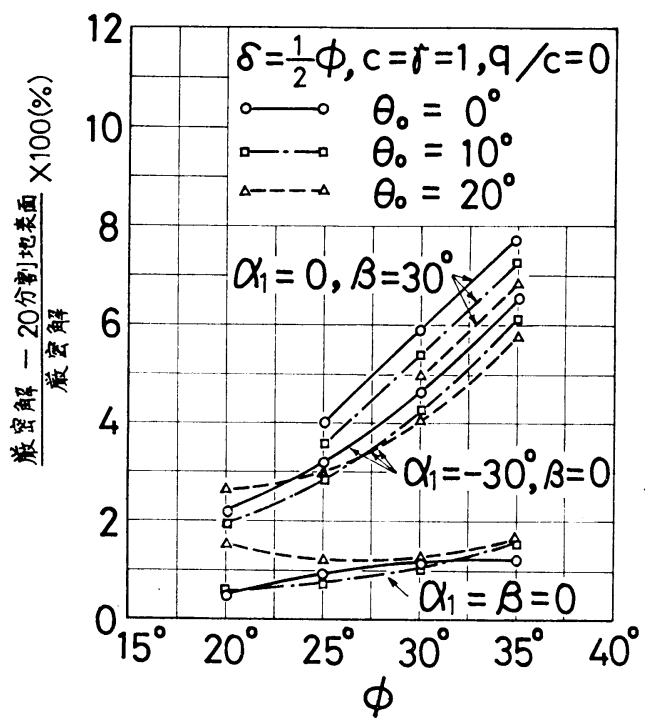

図一28 地表面 20 分割で求めた $\boldsymbol{K}_{P_{r}}$ の厳密解に対する誤差 
上述したことから, 地表面側から計算した結果は, 厳 密な值よりも小さくなることが明らかになったが，諸条 件で, どの程度の差を生ずるかを明確にする.

図一28 は $\delta=1 / 2 \phi, q / c=0$ に拈て, 厳密なる $K_{P r}$ に対する地表面側 20 分割の差を百分率で示した.

この差は $\left(\alpha_{2}-\alpha_{1}\right)$ が大になるほど大きい。ここに $\alpha_{2}$ 一 $\alpha_{1}$ は, 壁頂に打ける $O A$ 線の接線と壁面とのなす角 度であり， $\alpha_{2}$ は次式で与えられる。

$$
2 \alpha_{2}=\pi+2 \beta-\left(\tilde{\delta}^{\prime}-J^{\prime}\right)-2 " \text { " }
$$

そ机沖え,この図では $\beta=30^{\circ}, \alpha_{1}=0, \phi=35^{\circ}$ の場合 にその差が最も大となり， $7.8 \%$ に達する.

原点に扔ける $\left(\alpha_{2}-\alpha_{1}\right)$ の值は, 内部摩擦角 $\phi$, 地表 面傾角 $\beta$ が大なるほど，また壁面傾角 $\alpha_{1}$ が小なるほど 大である。生他の条件が同じ場合に，地震合成角 $\theta_{0}$ が小であるほど差は大になっている， $\alpha_{1}=\beta=0$ で注差 は最大 $1.5 \%$ 程度であり，その差はほとんど 無視でき る.また $\alpha_{1}>0$ では，この差はさらに小なることが予想 されるが，これは不連続線の解法を用いる領域になり， この差は考慮されない。

b) 厳密な $K_{P \gamma}$ と砂質土の地震時受働土圧係数 $K_{P E}$ の比較

粘性土の地震時受働土圧を直線分布におきかえて, $K_{P c}, K_{P \gamma}$ で表わしうることがわかり，いままた $K_{P_{r}}$ に厳密な值が求まった，しかしながら筆者らは，粘性土 の受㗢土圧算定の簡便法として， $K_{P \gamma}$ に砂質土の地震 時受働土圧係数 $K_{P E^{8}}{ }^{8)}$ を用いることができることを示 したので，ここで $K_{P E}$ を $K_{P \gamma}$ と比較する. $K_{P E}$ は 厳密な $K_{P \gamma}$ と比較して, 内部摩擦角 $\phi$ の值のいかんに かかわらず， $\beta=0, \alpha_{1}=-30^{\circ}$ のとき ${ }^{12)}, 1.0 \sim 3.0 \%$ 程 度小さい。 また $\beta=30^{\circ}, \alpha_{1}=0$ では $3.0 \sim 4.0 \%$ 程度小 である. $\alpha_{1}=\beta=0$ のときはその差は $1 \%$ 末満となり， $\alpha_{1}$ $=\beta=0$ で,さらに $\delta=0, \theta_{0}=0$ では両者は全く一致す る.

次に筆者らが表として提示した地表面 20 分割の $K_{P \gamma}$ を含めて大小関係を示すと, 厳密なる $K_{P \gamma} \geqq K_{P E}>$ 地 表面 20 分割の $K_{P \gamma}$ となる.したがって， $K_{P E}$ また は地表面 20 分割の $K_{P \gamma}$ は安全な值を与えることにな る。しかしながら $K_{P E}$ を使用する簡便法ではすべり面 も描けず，また $|\beta|>\phi$ の場合に，土圧が算定できない 欠点がある。

いま上述の 3 つの土圧係数間にわずかな差があって も，土圧合力は $K_{P c}$ によっても支配されるから，合力 の差は上述したほど大ではない，要するに $K_{P E}$ はわず かに安全側の值を与え, また地表面 20 分割の $K_{P r}$ も 安全側の值を与え, ともに実用に供される.

c) Lee らの計算值との比較

Lee らは速度場を加味して, 静的の受働土圧を算定し
た. 土圧合力を水平成分 $P_{P H}$ と鉛直成分 $P_{P V}$ に分け,

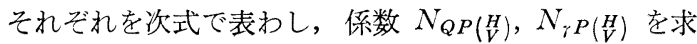
めて表䏡した。

$$
P_{P(V)}^{H}=c \cdot H \cdot N_{Q P(}\left(\begin{array}{l}
H \\
V
\end{array}\right)+\frac{1}{2} \gamma H^{2} N_{r} P\left(\begin{array}{l}
H \\
V
\end{array}\right)
$$

上式右辺の第 1 , 第 2 項はそれぞれ受㗢土圧のうち， $r$ 亿よらない成分と $c$ 亿よらない成分を表わす。

いまこれらの算定された倸数を筆者らの $K_{P c}, K_{P \gamma}$ と 比較するために, 次式で与えられる換算を行った.

$$
\begin{aligned}
& K_{P c}=\left(N_{Q P H} \cos \alpha_{1}-N_{Q P V} \sin \alpha_{1}\right) \cos \alpha_{1} \\
& K_{P_{\gamma}}=\left(N_{\gamma P H} \cos \alpha_{1}-N_{\gamma P V} \sin \alpha_{1}\right) \cos \alpha_{1}
\end{aligned}
$$

比較の一例は図一29 亿示した. 左の図は $K_{P_{c}}$ の比較 である.この $K_{P c}$ は $r=0$ とすれば，地表面上壁面の 条件のみで電算を使用せずに決定りされるので，筆者ら の行った地表面 20 分割ならびに綮密解は, 上もにLee らの結果と完全に一致している.

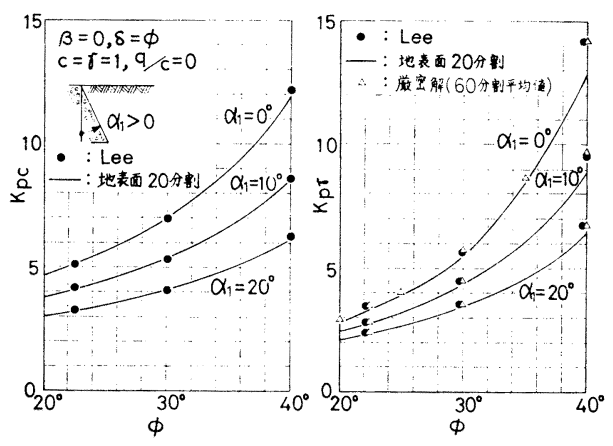

図一29 Lee の計算結果と筆者らの行った二つの 計算法の比較 $\left(\beta=0, \hat{o}=\dot{\phi}, \theta_{0}=0\right)$

図一29 の右の図の $K_{P_{r}}$ は $K_{P c}$ と同じく $\delta=\phi, \beta=0$, $\theta_{0}=0$ の場合で，筆者らも，Lee らもいずれも特異点の 解から得られた值である.筆者らの地表面から行った 20 分割による結果を実線で示している。筆者らの厳密解は Lee らの結果と一致している。このように Lee らが筆 者らの厳密解と一致している理由は，Lee らの計算が繰 り返し計算である一定值に収束してはじめて，次の計算 段階へ進むようなプロセスをとっているためと考えられ る. 筆者らの峳密解は一度の計算で得られるわけでない ので, 㛜密解としてのすべり線網を描けないのが久点で ある。

しかし，厳密解の $K_{P \gamma}$ を求めたのと同様な解析法で, 同一分割数の 2 者の計算結果から節点の座標の平均値を 求めれば，厳密なすべり線網を推定できる．すべり線網 についても Lee らの結果と比較することが望ましいが， Lee らはすべり線網の詳細な報告をしていないので，比 較することができない，筆者らは既述のように，単に分 割数を増加させたり, あるいは $\phi$ の平均值をとる方法 (Sokolovski の方法) を併用して精度をあげることにつ 
とめたが，あをりよい結果をうることができなかった. ここに示した地表面, 壁面からそれぞれ計算を行って求 めた值の平均値を採用する方法は前述のように精度もよ く,かつそれほどの複雑な手段をとらずに計算を進める ことができる利点がある.

\section{6. 結 語}

粘性土の地震時受働土压を算定するにあたって, 地震 合成角度 $\theta_{0}$ をパラメーターとして, Sokokovski の静 的土圧の算定法を全般的に挔大させることができた. 特 に不連続解においては, 高木の方法を攡壁土圧に適用し て, 原点近傍点の值を合理的に求めることを可能にし た. またより厳密な解として, 地表面から壁面に向かっ て計算を進めて求めた土压の值と, 壁面から地表面に向 かって計算を進めて求めた士圧の平均の值を採用するこ とにした. そのために，壁面から地表面に向かって計算 を進める方法を開発した. 得られた結果の要旨を示すと 次のよらになる.

（1）壁体前面の傾角 $\alpha_{1}$, 基礎地盤の傾角 $\beta$, 地震合 成角 $\theta_{0}$, 内部摩擦角 $\phi$, 壁摩擦角 $\delta$ をそれぞれ変化さ せたとき, $\left|\beta_{0}\right| \leqq \phi$ における粘性土の受働土圧の大きさ, ならびにすべり線の形状の変化の様相は, $c=0$ の砂質 土の場合と同じであった.

（2）地震力の作用下において，一般的に地震時の土 圧の分布は曲線で与えられる.しかしながら設計の便を 考えて, これを直線で表示し， $K_{P c}, K_{P r}$ の表を示し た. このらち $K_{P r}$ は曲線分布に対して小さめの值を与 えている. 直線分布にしたときの土圧合力の曲線分布に 対する誤差は $H^{\prime}=10$ では $1 \%$ 以下であった.

（3）地盤中に, 地表面に平行な応力の限界線が存在 する場合には, 得たる土圧 $\sigma_{n}$ の分布を直線でおきかえ ることができない場合が多い.このような場合は土圧の 分布を図面で示した. 地表面が水平な場合でも地震力が 大になるとこのような状態になる.

（4）不連続線の解を使用して求める場合に， $\varphi_{0} \fallingdotseq \phi_{0}{ }^{\prime}$ では第 4 境界值問題の適用が困難になる.このような場 合に特異点の解を強行しても, 土圧は近似的に決定され る. $\phi_{0}{ }^{\prime} と \phi_{0}$ の間に $30^{\circ}$ の差がある場合でも, 特異点 の解を強行して土圧だけは近似的に求められる.

（5）表一1，2 に示した地表面 20 分割による $K_{P r}$ を, 筆者らの厳密解と比較したら， $\alpha_{1}$ が小さな場合, ま
たは $\beta$ が大きい場合に， $8 \%$ 程度小なる結果を与えた. このような誤差は $\alpha_{2}-\alpha_{1}$ が大きくなるほど大である. しかしながら, 土圧合力としては $K_{P c}$ の值も大きく影 響するので, 土圧合力の誤差は半減されるものと考えら れる. またすでに筆者らが求めた砂質土の $K_{P E}$ を厳密 解と比較すると, 厳密解よりもわずかに小で, 地表面 20 分割の上述の $K_{P_{\gamma}}$ よりは大であった. 地表面 20 分割 の $K_{P \gamma}$ は $\left|\beta_{0}\right|>\phi$ でも土圧が算定でき，かつすべり面 が一度の計算で容易に求められるから, この算定法もこ れによる $K_{P_{\gamma}}$ の値もともに実用に供される.

(6) Lee らの粘性土の静的の受㗢土圧係数㲚者ら の厳密解と一致した.

この研究の図面のトレースは, 名大大学院生千田正孝 君と文部教官伊藤文隆君によった. 筆者らは両君の労に 感謝する. なお数值計算は名大大型計算機 センターの FACOM 230-60 によった.

\section{参考文 献}

1) Sokolovski, V.V. : Statics of soil media, 1954.

2）星埜 和・佐藤建吉共訳, ソコロフスキー蓄：土のよう な粒状体の力学, 1964, オーム社.

3）安部浩二・宮本 博訳, プラガー, ホッジ著：塑性学, 丸善, p. 134，1951 (訳は 1954).

4) Shield, R.T. : Mixed boundary value problems in soil mechanics., Quart. Appl. math. Vol. 11, No. 1, pp. 61 75, 1953 .

5) Sokolovski, V.V. : Some problems of soil pressure, Proc. of the 4th Inter. Conf. on SM \& FE 5/10, pp. 239 242, 1957.

6) 高木俊介: 土質力学の考え方 (8), 農業土木研究第 27 卷 第 6 号, p. 422, 1960.

7) Lee, I.K. \& Herington, J.R. : A theoretical study of the pressures acting on a rigid wall by a sloping earth or rock fill, Géotechnique 22 , No. 1 , pp. $1 \sim 26$, 1972.

8) Ichihara M., Mori N., Nakane S., Hirano I.: Passive earth pressure coefficient during earthquake, Memoirs of the Faculty of Engineering, Nagoya University, Vol. 25, No. 2, November, 1973, pp. 129 179.

9）市原松平：3.3 上圧 p. 41 「土留め構造物の設計法」, 土 質基礎工学ライブラリー 11, 土質工学会, 1975.

10）市原松平・森信夫：地震時受働土珪保数, 土木学会諭文 報告集, No. 215,1973 .

11）市原松平：地震時モールの円と先の推壁土圧への適用に ついて, 土木学会論文集, No. 136, pp. 25〜34, 1966.

12）市原松平・中根 進 : 粘性土の地震時受働土压の览密澥, 土木学会中部支部研究発韯会講演概要集, 昭和 50 年 1 月, pp. $165 \sim 166$.

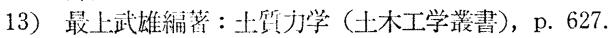

(1976.1.19. 受付) 